\title{
State Power to Prohibit Interstate Commerce
}

F ALL the opinions, monographs, treatises and articles which have been
written concerning the commerce clause of the Federal Constitution were laid end to end, they would reach from confusion to futility. An excuse seems the natural preface to adding further discussion of the subject. In the present case, that excuse is furnished by the recent ruling $^{1}$ of the Supreme Court that a state, with (and possibly without) the consent of Congress, can forbid the sale of harmless articles because of the conditions under which they were manufactured in another state, and a subsequent decision that the national government can forbid the interstate transportation of such goods. ${ }^{2}$ These new developments would seem to rock the doctrine supposedly established by the first Child Labor $\mathrm{Case}^{3}$ to its very foundations, and warrant a reexammation of the record in an attempt to formulate anew, in the light of the evidence now available, the basic principles which control the answers to the questions: When, and by whom, may interstate cornmerce be prohibited?

Prior to the adoption of the Constitution interstate commerce was a branch of foreign commerce, each state enjoying full authority to tax, restrict, or prohibit it at pleasure. And it has been said that "None of that power was abridged by that instrument except as restrained by constitutional safeguards, and hence none was lost by the adoption of the Constitution. The Constitution, whilst distributing the preexisting authority, preserved it all." 4 If this be true, power to forbid interstate commerce must now be vested either in Congress or the state legislatures, or both, except in so far as it is restricted by "constitutional safeguards" found in the body of the Constitution or the amendments.

This need not imply that arbitrary power to prohibit interstate comnerce still exists in either the national or state governments. With the

1 Whitfield v. Ohio (1936) 297 U. S. 431, holding that Ohio can make criminal the sale of work shirts manufactured by prison labor in Alabama.

2 Kentucky Whip and Collar Co. v. Illinois Central R. Co. (1937) 299 U.S. 334, sustaining the Ashurst-Sumners Act, 49 STAT. (1935) 494, $\S \S 1,3,49$ U. S. C. A. (1936 Supp.) \& 61.

3 Hammer v. Dagenhart (1918) 247 U.S. 251.

4 White, J., on behalf of himself and Fuller, C. J., and Peckham and Holmes, J.J., dissenting in Northern Securities Co. v. United States (1904) 193 U. S. 197, 399. He repeated the same doctrine on behalf of an unanimous court in United States v. Bennett (1914) 232 U. S. 299, 306. And see Passenger Cases (1849) 48 U. S. (7 How.) 283, 394; Intermountain Rate Cases (1914) 234 U. S. 477, 493; Burnet v. Brooks (1933) 288 U. S. 378, 404; Corwin, Congress' Power to Prohibit Commerce (1933) 18 CoRN. L. Q. 477, 499. 
adoption of the Constitution $I$ assume, as the Court has assumed, ${ }^{5}$ that the Umited States became one "free trade" area. In vesting power in Congress to "regulate Commerce ... among the several States" 6 the Constitution must have contemplated uniform regulations, except where flexibility is permissible to fit national rules to the peculiarities of the internal commerce of particular states as regulated by state law. ${ }^{7}$ Nor could such federal laws, even though uniform in application throughout the nation, interfere with what the Court should consider legitimate activities in the absence of a valid justification for such interference. "Due process," of course, forbids this; and though we must guard against projecting back into history the modern interpretation of that magic phrase, we must recall that the Court apparently stood ready, in the absence of express constitutional himitations, to strike down arbitrary legislation in the name of "natural law," "the great first principles of the social compact," or "the spirit of the Constitution." 8

A second hine of reasoning, occasionally assumed to lead to an opposite conclusion, in reality is in no way contradictory. The power to regulate commerce among the states is conveyed to Congress in the same clause, and by the same words, as the power to regulate commerce with foreign nations. ${ }^{9}$ While it is not unusual for the same word or group of words to be used in different meanings even in the same document, the phrase "regulate commerce" occurs but once in this clause, and in the first case in which the Court was called upon to construe it Chief Justice Marshall concluded that "it must carry the same ineaning throughout the sentence." 10 Any other conclusion, as Professor Corwin has expressed it, would be "a novelty to the science of hermeneutics and probably to that of hinguistics as well." 11 Now experience has amply demonstrated that Congress' control over foreign commerce is absolute. If, then, "the two powers are undoubtedly of the same class and character and equally extensive," 12 does it not follow that Congress has power to

5 West v. Kansas Natural Gas Co. (1911) 221 U. S. 229, 255 ; Baldwin v. Seelig (1935) 294 U. S. 511, 526.

6 "The Congress shall have power ... to regulate Commerce with foreign Nations, and among the several States, and with the Indian Tribes; . . " U. S. Const., Art. I, $\S 8$, cl. 3.

7 National statutes dependent for their meaning upon the laws of the states have been uniformly sustained. E. g., United States v. Hill (1919) 248 U. S. 420; Kentucky Whip and Collar Co. v. Ilinois Central R. Co., supra note 2; The Wilson v. United States (1820) 30 Fed. Cas. No. 17,846; Cf. Ex. parte Siebold (1879) 100 U. S. 371.

${ }^{8}$ See the authorities cited in Grant, The Natural Law Background of Due Pracess (1931) 31 CoL. L. Rev. 56.

${ }^{9}$ See supra note 6.

10 Gibbons v. Ogden (1824) 22 U. S. (9 Wheat.) 1, 194.

11 Corwin, The Conminere Power versus States Rights (1936) 50.

12 Bowman v. Chicago \& N. W. R. Co. (1888) 125 U. S. 465, 482. 
prohibit interstate commerce as its fancy dictates? The answer is that this need not follow. Nor is the difference due to the fact that whereas the sole source of congressional jurisdiction over interstate commerce is the power "to regulate Commerce," its control of foreign commerce is bolstered by its supremacy in the field of international relations in general, since the commerce clause standing alone has been accepted from the first as an adequate basis for boycotts. ${ }^{13}$ The correct distinction would seem to be that although the grants are equally extensive, that to regulate interstate commerce is subject to "due process" limitations froin which the other is free. "No individual has a vested right to trade with foreigu nations." 14 While the Constitution envisaged a gigantic free trade unit, clearly no foreigu countries were contemplated as embraced within its area.

So far as the powers of Congress are concerned we may summarize, then, with the aphorism that in interstate commerce "restraint is the exception, hiberty is the rule." Any attempt to interfere with freedom of intercourse must be justified by reasons which satisfy the tests of "due process." The possible existence of other limitations upon congressional power to prohibit commerce is a question which may well be left for later considerations.

"It is admitted that, in regard to the commercial, as to other powers, the states cannot be held to have parted with any of the attributes of sovereignty which are not plamly vested in the federal government" or forbidden by constitutional safeguards applicable to them. ${ }^{15}$ And even where legislative authority is vested in Congress the states may still retain a subordinate authority, since concurrent powers, and even coordinate exercises of such powers, are no strangers to our constitutional system. ${ }^{16}$ Hence it is not possible, in delimiting the commercial powers of the states, to follow the inviting procedure of determining the scope of federal powers and deducting them fron the total of powers not expressly forbidden to the states. We are faced with the task of discovering other rules.

Whatever the scope of state powers, one fact is evident: they cannot be used in such a manner as to discriminate against interstate commerce in favor of local enterprise. ${ }^{17}$ It is beyond the scope of this article to

${ }^{13}$ See Marshall, C. J., in Gibbons v. Ogden, supra note 10, at 191-2; STORY, Commentaries on the Constitution (3d ed. 1858) $§ 1064$.

14 Buttfield v. Stranahan (1904) 192 U. S. 470, 493, quoted in Oceanic Steam Navigation Co. v. Stranahan (1909) 214 U. S. 320, 335, and The Abby Dodge (1912) 223 U. S. 166, 176 .

15 McLean, J., in Passenger Cases, supra note 4, at 394.

${ }^{16}$ See Biklé, The Silence of Congress (1927) 41 Harv. L. Rev. 200; Grant, The Scope and Nature of Concurrent Power (1934) 34 CoL. L. REv. 995.

17 A dictum in State Board of Equalization v. Young's Market Co. (1936) 299 U. S. 59, 63, that a state "may permit the domestic manufacture of beer and ex- 
discuss the constitutional basis of this rule, the existence of which seems never to have been doubted; and whatever its origin, it is evident that today it finds ample support in the post-1886 construction of the "equal protection of the laws" clause of the Fourteenth Amendment coupled with the "free trade" concept derived from the commerce clause. In short, whereas Congress can ride rough-shod over the wishes of particular states and thus give us a divergence between the rules governing interstate trade and those governing intrastate activities, the most that a state can do is to extend to interstate commerce the same policies and programs that it apphies to intrastate affairs. And here the states, like Congress, are subject to the requirements of "due process." Again the possible existence of additional himitations may be postponed for later discussion.

We must not overlook the fact that in interstate commerce there are two groups of states, sometines with divergent interests, the importing and the exporting. And we must guard against falling into error in assuming, as many have, that merely because neither Congress nor the importing state can forbid a given type of commerce, power to prohibit it has dissolved into thin air. It nuay, instead, be vested in the exporting states. The problem, then, divides logically into three parts: When may a state prohibit importation? When may it prohibit exportation? When may Congress prohibit interstate commerce, and thus in effect forbid both exportation and importation? The present paper is restricted to the first of these three questions, although it necessarily throws light upon the third. I propose to consider the subject historically as well as analytically.

\section{THE EARLY CASES}

Due largely to a paucity of legislation, the Court was not called upon to discuss the power of Congress to forbid interstate commerce until the present century was nearly upon us. Few of the early cases were directly concerned with national authority. In Gibbons v. Ogden ${ }^{18}$ the Court rejected the contention that congressional power to regulate commerce embraces only buying and selling and held that it includes transportation, and hence navigation, as well. Brown v. Maryland ${ }^{19}$ held that congressional permission to import from abroad carries with it authorization to sell, and intimated that a similar rule would apply to interstate commerce, while United States v. Coombs ${ }^{20}$ sustained federal penalties for the larceny of goods in interstate commerce. But even these opinions owe much of their importance to obiter discussions of the scope of related state powers.

clude all made without the State" indicates that the Twenty-First Amendment will be construed to furnish an exception to this rule.

18 Supra note 10.

19 (1827) 25 U. S. (12 Wheat.) 419.

20 (1838) 37 U.S. (12 Pet.) 72. 
Perhaps few opinions have been more misrepresented than that of John Marshall in the first commerce clause case, Gibbons v. Ogden. ${ }^{21}$ The Chief Justice did not hold that the Constitution, by vesting the power to regulate commerce in Congress, took it away from the states. This statement, to be sure, was made in this case; but it was in the concurring opimion of Justice Johnson, ${ }^{22}$ Marshall, having raised the question, "Whether it is surrendered by the mere grant to Congress, or is retained until Congress shall exercise the power?", added: "We may dismiss that inquiry, because it has been exercised, and the regulations which Congress deemed it proper to make, are now in full operation." 23 And when he came to the crucial question, that of conflict between the two sets of laws, he held: "Should this collision exist, it will be immaterial whether those [i.e., state] laws were passed in virtue of a concurrent power 'to regulate commerce with foreign nations and among the several states,' or, in virtue of a pawer to regulate their domestic trade and police." ${ }^{24}$ This indicates extreme care to guard against expressing a final opinion on the question, and as le was equally circumspect in Brown v. Maryland ${ }^{25}$ and Wilson v. Blackbird Creek Marsh Co. ${ }^{26}$ le died apparently still of an open mind.

In the very act of leaving this question open, the Court, through the Chief Justice, made it clear that it had no doubt as to the existence of overlapping state and national powers. The state may apply its inspection laws to foreign and interstate commerce alike, although Congress could probably take over this field should it wish to do so; ${ }^{27}$ state quarantine and health laws are valid in the absence of conflicting national rules; ${ }^{28}$ even navigation (the subject before the Court) can be governed by local pilotage regulations until Congress supplants them with a national scheme. ${ }^{29}$ Justice Johnson willingly joined in this conclusion, agreeing that "The line cannot be drawn with sufficient distinctness between the municipal powers of the one, and the commercial powers of the other" to avoid collision, ${ }^{30}$ and that "It is no objection to the existence of distinct, substantive powers, that, in their application, they bear upon the same subject." 31

Although both the "concurrent power to regulate commerce" and the

21 (1824) 22 U. S. ( 9 Wheat.) 1.

22 Ibid. at 222, 226, 231-2, 236.

23 Ibid. at 200.

24 Ibid. at 210.

25 Supra note 19.

26 (1829) 27 U. S. (2 Pet.) 245.

$2 \pi$ Gibbons v. Ogden, supra note 21, at 203, 204.

$28 \mathrm{Ibid}$. at 205, 206.

$20 \mathrm{Ibid}$. at $207,208$.

$30 \mathrm{Ibid}$. at 238.

31 Ibid. at 235 . 
"national commerce power-state police power" concepts pointed to the same conclusion in each of the problems instanced by Marsliall, it is evident that the former postulates a state power no less sweeping in scope than that of Congress itself, while the latter is meaningless witlout further definition and could, coupled witl a narrow interpretation of "police power," effectively place the states in a judicial straitjacket. The importance of the choice was enhanced by the ruhing in Brown $v$. Maryland ${ }^{32}$ that the national commerce power "must be capable of authorizing the sale of those articles which it introduces. . . . Sale is the object of importation, and is an essential ingredient of that intercourse, of which importation constitutes a part." 33 Although the majority placed its ruling upon the narrow ground that the state tax was "in opposition to the act of Congress," ${ }^{34}$ Justice Thompson, who dissented, proved correct in his assertion that it leaves even the power of the state to forbid the sale of what it considers noxious goods at the mercy of congressional discretion. ${ }^{35}$

Immediately following Marshall's death, debate broke out in earnest in New York v. Miln..$^{36}$ The state of New York required the masters of vessels transporting passengers in interstate or foreign commerce to furnish a list of all passengers and to post a bond gnaranteeing that none of those disembarking would become a public charge. This is a type of legislation now accepted as a normal exercise of national power. ${ }^{37}$ Yet the majority, possibly in a reaction against Marshall's extreme nationalism, held that it was solely a matter of police and hence within the exclusive jurisdiction of the states. ${ }^{38}$ This made it unnecessary to pass upon the right of the states to exercise the commerce power, although they intimated that this might also be done. ${ }^{39}$ Justice Story filed a vigorous dissenting opimion, in which he defended three contentions: First, "the power given to Congress to regulate commerce ... has been deemed exclusive"; ${ }^{40}$ second, it is beyond the authority of the states, even when proceeding under their police powers, to "trench upon the authority of congress in its power to regulate commerce"; 41 and third, this act did trench upon this authority, since "No one can well doubt, that if the

32 (1827) 25 U. S. (12 Wheat.) 419.

33 Ibid. at 446-7.

34 Ibid. at 448 .

35 Ibid. at 456-7. See Leisy v. Hardin (1890) 135 U. S. 100, and the other liquor cases discussed infra.

36 (1837) 36 U. S. (11 Pet.) 102.

37 See 8 U.S.C.A. (1926) \$\$148, 156, 158, 171.

3836 U. S. (11 Pet.) at 139. See the concurring opinion of Thompson, J., ibid. at 143,151 .

39 Ibid. at 139, 145-6, 148, 149, 152.

40 Ibid. at 158.

$\$ 1$ Ibid. at 156. 
same act had been passed by congress, it would have been a regulation of commerce; and im that way, and in that only, would it be a constitutional act of congress." 42 Hence he concluded that the state act would be invalid even if Congress had passed no law upon the subject; but he bolstered this conclusion with a finding of actual conflict with existing national statutes. ${ }^{43}$

Justice Story's opinion made it painfully evident that the "police power" concept was proving of no assistance in aiding clarity of thought. His conclusion that it could not justify overlapping state and national power was entirely out of keeping with the purpose for which it had been invented, and even with certain statements in his own opinion. ${ }^{44}$ And although but a year passed before he abandoned this view, defending not only the concurrent power of the nation and the states to punish the larceny of goods in interstate commerce but also the coordinate exercise of these powers, ${ }^{45}$ the damage had been done. Eleven years later ${ }^{40}$ we find Justice Wayne insisting upon the next logical step: so far as commerce is concerned the police power has been divided between the nation and the states. This is the view that prevails today. ${ }^{47}$ Thus a term intended to be descriptive of state power came, instead, to designate a particular type of power regardless of the government exercising it.

Although advanced on behalf of a doctrine of nationalism, Story's thesis had the added disadvantage of endangering congressional power. If the mere authority of Congress to legislate, although unexercised, was a constitutional barrier to state legislation, every decision sustaining state activity constituted a silent ruling that Congress could not enter this field. Nor could judges who were the least interested in preserving an important role for the states, faced with the contention that the national commerce power is exclusive, willingly concede a wide scope to that power. Witness the rapid reversal which had taken place in the

42 Ibid. at 157 .

43 Ibid. at 159.

44 See ibid. at 156 .

45 United States v. Coombs, supra note 20.

46 Passenger Cases (1849) 48 U. S. (7 How.) 283, 424.

47 "Congress can certainly regulate interstate commerce to the extent of forbidding and punishing the use of such commerce as an agency to promote immorality, dishonesty or the spread of any evil or harm to the people of other States from the State of origin. In doing this it is merely exercising the police power, for the benefit of the public, within the field of interstate commerce." Taft, C. J., in Brooks v. United States (1925) 267 U. S. 432, at 436-7. See Hoke v. United States (1913) 227 U. S. 308; Caminetti v. United States (1917) 242 U. S. 470, 492; Kentucky Whip and Collar Co. v. Illinois Central R. Co., supra note 2, at 347. Judge Cooley foresaw its acceptance, stating: "Congress may establish police regulations, as well as the States; confining their operation to the subjects over which it is given control by the Constitution." Cooley, Constitutionat Lmmitations (3d ed. 1874) *586. 
attitude toward the transportation of persons. Marshall had assumed that this so clearly constitutes commerce as to be beyond debate; ${ }^{48}$ yet the majority in the Miln case held that whereas "goods are the subject of commerce, ... persons are not." 49 It was becoming obvious that the successful defense of adequate national powers necessitated acceptance of a broad scope of concurrent state authority. The new Chief Justice addressed himself to this task in Peirce v. Nerw Hampshire, reported together with others in the License Cases. ${ }^{50}$ As this is the most important commerce clause decision of the first half of the mineteenth century, it merits brief consideration.

The New Hampshire law forbade the sale of distilled spirits, in any quantity, without a hicense from the selectmen of the town; and "it was admitted, on the argument, that no hicenses are issued," as the act "had in view an entire prohibition from use of spirits and wines of every description." 51 The plaintiffs in error, who were merchants in Dover, New Hampshire, purchased a barrel of gin in Boston, brought it to Dover, and sold it in the cask in which it was imported, without a hicense. For this sale they were indicted, convicted, and fined. It was conceded that, according to the doctrine in Brown v. Maryland, ${ }^{52}$ the New Hampshire law "acts directly upon an import from one State to another, while in the hands of the importer for sale, and is therefore a regulation of commerce, acting upon the article while it is within the admitted jurisdiction of the general government, and subject to its control and regulation." " 33 Four judges were for reversing this doctrine, Justice Woodbury going so far as to say that "the subject of buying and selling within a State" is one "exclusively belonging to the power of the State over its internal trade," while Justice Grier wrote: ". . . the States have a right to prohibit the sale and consumption of an article of commerce which they beheve to be pernicious in its effects, and the cause of disease, pauperism, and crime. . . 'In relation to these, the authority of a State is complete, unqualified, and conclusive'." 55 Only the vote of the Chief Justice was necessary to give a majority for this view. But

48 See his opinions in The Wilson v. United States, supra note 7, at 438 , and Gibbons v. Ogden, supra note 10, at 215-6.

49 New York v. Miln, supra note 36, at 136. See Groves v. Slaughter (1841)

40 U. S. (15 Pet.) 449, 505-8; Passenger Cases, supra note 46, at 283, 406, 466, 467,477 .

50 (1847) 46 U. S. (5 How.) 504.

51 Ibid. at 601.

62 Supra note 19.

53 Taney, C. J., 46 U. S. (5 How.) at 578.

54 Ibid. at 620 . 594,612 .

55 Ibid. at 631 . And see the opinions of McLean and Daniel, J. J., ibid. at 
Taney chose, instead, to abide by the previous ruling, and to sustain the statute upon the doctrine of concurrent power. He wrote:50

“. . . the grant of power to the federal government is not an absolute and entire prohibition to the States, but merely confers upon Congress the superior and controlling power. . . . As Congress bas made no regulation on the subject, the traffic in the article may be lawfully regulated by the State as soon as it is landed in its territory, and a tax imposed upon it, or a license required, or the sale altogether prohibited, according to the pohicy which the State may suppose to be its interest or duty to pursue."

This ruling, which was in keeping with his statements in previous opinions, ${ }^{57}$ had the support of a clear majority of his colleagues. ${ }^{58}$

It was at this point that Taney played his ace. Turning to the "police power," theretofore used as a convenient excuse for sustaining interferences by the states with freedom of trade, he wrote:50

". . . It has been said, indeed, that quarantine and health laws are passed by the States, not by virtue of a power to regulate commerce, but by virtue of their police powers, and in order to guard the lives and health of their citizens. This, however, cannot be said of the pilot laws, which are yet admitted to be equally valid. But what are the police powers of a State? They are nothing more or less than the powers of government inherent in every sovereignty to the extent of its dominions. And whetber a State passes a quarantine law, or a law to punish offences, or to establish courts of justice, or requiring certain instruments to be recorded, or to regulate commerce within its own limits, in every case it exercises the same powers; that is to say, the power of sovereignty, the power to govern men and things within the limits of its dominion. It is by virtue of this power that it legislates; and its authority to make regulations of commerce is as absolute as its power to pass health laws, except in so far as it has been restricted by the constitution of the United States. And when the validity of a State law making regulations of commerce is drawn into question in a judicial tribunal, the authority to pass it cannot be made to depend upon the motives that may be supposed to have influenced the legislature, nor can the court inquire whether it was intended to guard the citizens of the State from pestilence and disease, or to make regulations of commerce for the interests and convenience of trade."

This bold exposé of the artificiality of much of the previous reason-

56 Ibid. at 583, 586.

57 See Groves v. Slaughter, supra note 49, at 509-10; Prigg v. Pennsylvania (1842) 41 U. S. (16 Pet.) 539, 627. An excellent summary of Taney's views is given in Frankfurter, Taney and the Commerce Clanse (1936) 49 Hanv. L. Rev. 1286.

58 See the opmions of Catron, Daniel, Nelson, and Woodbury, J. J., 46 U. S. (5 How.) at $607-8,615,618,624$. Even McLean, J., seems to have swung temporarily to this view, basing his concurrence upon the findimg, "There is no act of Congress to which the license law, as applied to this case, can be held repugnant." Ibid. at 595. But Grier, J., chose to rest his concurrence solely upon the ground that the states have exclusive jurisdiction over the sale of merchandise, and hence refused to pass judgment upon "the question of the exclusiveness of the power of Congress to regulate counmerce ...." Ibid. at 631 .

$59 \mathrm{Ibid}$. at $582-3$. For a modern application of this reasoning, see Sligh v. Kirkwood (1915) 237 U. S. 52, 58-9. 
ing sounded the death knell of the "national commerce power-state police power" concept. Having proved capable, with an equal showing of logic, of supporting Story's contention that there is no overlapping, Johnson's concession of slight parallehsm, a growing insistence upon still greater duplication, and Taney's final affirmance of total identity, the doctrine was tendered a glorious, if quite confused, swan song in the Passenger Cases, ${ }^{60}$ and then gave way to the first rough draft of the modern rule in Cooley v. Board of Wardens. ${ }^{61}$

\section{THE COOLEY CASE RULE}

The first Congress had provided that "until further provision shall be made . . . all pilots . . . shall continue to be regulated in conformity with the existing laws of the States ... or with such laws as the States may respectively ... enact for the purpose. . ." 62 Unless we are to entertain the unwarranted supposition that the national legislature considered itself capable of returning to the states powers taken from them by the Constitution, this statute would seem to indicate three congressional assumptions: First, the commerce clause embraces pilotage; second, a concurrent power to regulate pilotage is retained by the states; third, it is wise to give expression to the intention that the states be left free to assert their authority, lest congressional inaction be construed as indicative of a desire that no action be taken. With this positive declaration from Congress, and with the apparent approval of the Supreme Court, $^{63}$ the states continued to assert full authority over this subject. But in 1851 Cooley, refusing to pay pilotage fees assessed under a Peunsylvania act of 1803 , carried his appeal to the Supreme Court and thus gave rise to the first case in which pilotage regulations became a subject for judicial decision rather than dicta.

Justice Daniel concluded that the regulation of pilotage does not fall "within that power of commercial regulation vested by the Constitution in Congress," which is concerned with "the terms on which commercial engagements may be prosecuted; the character of the articles which they may embrace; the permission or terms according to which they may be introduced ..." rather than "the means of precaution and safety adopted ... for the preservation of vessels and cargoes, and the lives of navigators or passengers." 04 Hence lie supported exclusive, rather than

60 See stupra note 46.

61 (1851) 53 U. S. (12 How.) 299.

621 STAT. (1789) $54, \S 4$.

63 See Gibbons v. Ogden, supra note 10, at 207-8, 238; New York v. Miln, supra note 36, at 148; License Cases, supra note 50, at 580; Passenger Cases, supra note 46 , at 402,497 .

64 Supra note 61 , at $325-6$. 
subordinate, state jurisdiction. ${ }^{65}$ But the majority, in an opinion by Justice Curtis, held that pilotage laws "do constitute regulations of navigation, and consequently of commerce, withm the just meaning of this clause of the Constitution," 66 which brought them "unavoidably to the consideration of the question, whether the grant of the commercial power to Congress, did per se deprive the states of all power to regulate pilots." 67 Their reply was couched in the following language:"8s

"... Now, the power to regulate commerce, embraces a vast field, containing not only many, but exceedingly various subjects, quite unlike in their nature; some imperatively demanding a single uniform rule, operating equally on the commerce of the United States in every port; and some, like the subject now in question, as imperatively demanding that diversity, which alone can meet the local necessities of navigation.

"Either absolutely to affirm, or deny that the nature of this power requires exclusive legislation by Congress, is to lose sight of the nature of the subjects of this power, and to assert concerning all of them, what is really applicable but to a part. Whatever subjects of this power are in their nature national, or admit only of one uniform system, or plan of regulation, may justly be said to be of such a nature as to require exclusive legislation by Congress. That this cannot be affirmed of laws for the regulation of pilots and pilotage, is plaim. . . The nature of the subject when exammed, is such as to leave no doubt of the superior fitness and propriety, not to say the absolute necessity, of different systems of regulation, drawn froin local knowledge and experience, and conformed to local wants."

Only one judge, McLean, dissented. ${ }^{69}$

This test would seem to be better fitted for legislative than judicial application. The Court, indeed, seems to have inclined toward such a view, for in reaching the decision that "the nature of the subject" before it did not call for "one uniform system, or plan of regulation" it placed great reliance upon the Act of 1789,70 which, it stated, ${ }^{71}$

"... contains a clear and authoritative declaration by the first Congress, that the nature of this subject is such, that until Congress should find it necessary to exert its power, it should be left to the legislation of the states; that it is local and not national; that it is likely to be the best provided for, not by one system, or plan of regulations, hut by as many as the legislative discretion of the several states should deem applicable to the local pecuharities of the ports within their limits.

"Viewed in this light, so much of the act of 1789 as declares that pilots shall continue to be regulated 'by such laws as the states may respectively

65 It is evident from his prior opinions that he was willing to accept concurrent power if national authority could be established. See, especially, Passenger Cases, supra note 46 , at 497 .

66 Supra note 61, at 316.

67 Ibid. at 318.

68 Ibid. at 319-20. Italics added.

$69 \mathrm{Ibid}$. at 321 . His reasoning, not new to this case, that if the states retain a concurrent power their laws will not yield to conflicting national statutes, utterly disregarded the fact that federal laws, no lesg than the Constitution itself, are "the supreme law of the land." See Grant, op. cit. supra note 16, at 1014.

70 Supra note 62.

71 Supra note 61 , at $319-20$. 
hereafter enact for that purpose,' instead of being held to be inoperative, as an attempt to confer on the states a power to legislate, of which the Constitution had deprived them, is allowed an appropriate and important signification. It manifests the understanding of Congress, at the outset of the government, that the nature of this subject is not such as to require its exclusive legislation. The practice of the states, and of the national government, has been in conformity with this declaration, from the origim of the national government to this time. ..."

It will be noted, however, that the opinion of Congress, although clear and explicit, was not accepted as binding upon the Court, but only as evidence of the fact to be determined: Is "the nature of the subject" such as to lend itself to diversity of regulation? This, apparently, was to be a judicial question, and to this extent the new rule differs markedly from the proposed doctrine that the states have full authority to legislate on any subject "coming confessedly within the power to regulate commerce, until congress adopts a systen of its own." 72 It could have been accepted only as a conpromise rule following what must have been an exceptionally interesting interchange of ideas around the conference table.

Would the Court undertake to nrark out this hine separating exclusive from concurrent powers by "the gradual process of exclusion and inclusion"? If so, we could confidently look forward to ultimate errors, if not serious difficulties. Questions of fact, particularly those turning upon inatters of degree, do not lend themselves to the lawyer's technique of stare decisis. ${ }^{73}$ There was even the possibility that in delimiting this line the Court would look priniarily to the past rather than to the future, thus crystallizing "the practice of the states, and of the national governnent" into rules for the future rather than nere evidence of those rules. But we nust guard against exaggerating the danger from such a step. Contrary to general belief, existing practices, at least so far as reflected in opinions of the Court, were extremely liberal in sustaining state laws prohibiting commerce. Indeed, the first serious problen arising from the new rule resulted from the failure to follow these liberal precedents rather than the too literal application of them.

72 Thompson, J., in New York v. Miln, supra note 36, at 148.

73 The California courts have been forced to recognize this in handling a somewhat similar problem in the division of powers between the state and local governments. Is the regulation of highway traffic a "municipal affair," or does it demand state-wide uniformity? In "the horse and buggy days" it confessedly fell in the former category, while long before the advent of the supercharged V-eight it had becoine a state affair. In recognizing this change, the court stated: "The term 'municipal affair' is not a fixed quantity, but fluctuates with every change in the conditions upon which it is to operate." Helmer v. Superior Court (1920) 48 Cal. App. 140, at 141-2, 191 Pac. 1001, followed in Ex parte Daniels (1920) 183 Cal. 636, $192 \mathrm{Pac}$. 442. As under the California constitution municipal ordinances override state laws on "municipal affairs," serious difficulties would have arisen from an attempt to cling to the former classification. 


\section{STATE LAWS PROHIBITIYG COMIMERCE}

It has become the accepted practice to assert that during the first sixty years of its history the Supreme Court was busily occupied whittling away the powers of the states over interstate commerce. The record does not sustain this assumption. There were only three cases ${ }^{i 4}$ in which state laws regulating any phase of commerce, either interstate or foreign, were set aside, and in all three the ruling was expressly placed upon the ground that Congress had already occupied the field with regulations with which the state laws were in conflict. The statute involved in Brown v. Maryland ${ }^{75}$ suffered the additional defect of discriminating against foreign commerce in favor of local trade. Not one statute prolibiting the importation or sale of articles considered by the states to be undesirable merchandise was struck down, ${ }^{76}$ while an unanimous opinion in the License Cases $^{77}$ sustained the states in applying their own theories of health and morahity to intoxicants arriving through interstate commerce. A review of the decisions reveals the all but unanimous opinion that the states were free to do this in all cases, which alone can explain the failure of litigants to contest the issue.

Health. The Constitution provides, "No State sliall, without the Consent of the Congress, lay any Imposts or Duties on Imports or Exports, except what may be absolutely necessary for executing its inspection Laws: ..."78 Unless we are to assume, with Marshall, that "inspection laws" relate solely to exports, ${ }^{79}$ this recognition of the right to inspect must carry with it power to refuse entry to articles which fail to measure up to the required standard. Otherwise inspection would be much ado about nothing. But if the Court was correct in its recent assumption that this clause applies solely to international trade, ${ }^{80}$ it furnishes no basis, except by analogy, for excluding infectious or noxious goods offered in the course of interstate trade. Yet Congress took no

74 Gibbons v. Ogden, supra note 10; Brown v. Maryland, supra note 19; Passenger Cases, supra note 46.

75 Supra note 19.

76 No doubt the ruling in Brown v. Maryland, supra note 19 , caused the states to refrain from applying their sumptuary legislation to goods imported from abroad and still in the hands of the importer in the original packages, but this was due to a supposed conflict with existing national legislation governing such commerce rather than a want of state power. It seems evident from a reading of the opinion that had Congress amended its laws to permit state regulations to apply, the Court would have sustained them.

77 Supra note 50.

78 U. S. CoNst., Art. I, $\S 10$, cl. 2.

79 Gibbons v. Ogden, supra note 10, at 203: "The object of inspection laws, is to improve the quality of articles produced by the labor of a country; to fit them for exportation. . . . They act upon the subject, before it becomes an article of foreign commerce, or of commerce among the states, and prepare it for that purpose." 80 Baldwin v. Seelig, supra note 5 , at 522 . 
action until 1796, when it merely provided that "the President . . . be authorized to direct the revenue officers . . . to aid in the execution of quarantine, and also in the execution of the health laws of the states ...." $\$ 1$ This statute was reenacted, with amendments which need not concern us here, in $1799,{ }^{82}$ and is the core of the present law ${ }^{83}$ Obviously it proceeded on the theory that state quarantine and health laws are constitutional; and when the Court's attention was called to them in Gibbons v. Ogden, it replied, through Marshall, that "the constitutionality of such laws has never, so far as we are informed, been denied." 84 Similar statements were made at frequent intervals by other judges. ${ }^{85}$ Indeed, the vahidity of such a state statute seems never to have been contested in the Supreme Court until 1886, when it was sustained. ${ }^{86}$ Needless to say, the Court likewise pointed out that this power involves "the right to examine articles which are imported, ... and if any of them are found to be unsound, or infectious, to cause them to be removed, or destroyed," $\$$ even Justice McLean conceding that "they [the states] may guard against the introduction of anything which may corrupt the morals, or endanger the health of their citizens." 88 The Court was equally clear as to the right of the states to exclude diseased persons. ${ }^{89}$

Morality. The statement just quoted from Justice McLean, which he had previously elaborated ${ }^{90}$ specifically to include "hicentious publications," is typical of the reaction of the judges during the entire period under discussion. As stated by Justice Woodbury, "It is conceded that the States may exclude pestilence, either to the body or mind, shut out the plague of cholera, and, no less, obscene paimtings, lottery tickets, and convicts." 91 Possibly he had Cohens v. Virginia ${ }^{92}$ in mind when speaking

811 STAT. (1796) 474.

821 Stat. (1799) 619, Rev. Stat. (1878) $\$ 4792$.

8327 STAT. (1893) 450, § 3, 42 U.S. C.A. (1926) § 92. Non-waterborn commerce seems to have been left exclusively to the states until 1884, when Congress passed its first statute regulating interstate commerce in diseased livestock. 23 STAT. (1884) $32, \S 6,21$ U.S. C.A. (1926) § 114.

84 Supra note 10, at 205.

85 See New York v. Miln, supra note 36, at 147, 156; License Cases, supra note 50, at 630; Passenger Cases, supra note 46 , at 424 . And see references given infra notes 87 and 88 .

86 Morgan's S. S. Co. v. Louisiana Board of Health (1886) 118 U. S. 455.

87 New York v. Miln, supra note 36, at 142. See License Cases, supra note 50 , at $581,632$.

88 Passenger Cases, supra note 46 , at 400.

89 License Cases, supra note 50, at 628; Passenger Cases, supra note 46, at 406, 414. It has since been held that even bealthy persons may be excluded from a diseased area. Morgan's S. S. Co. v. Louisiana Board of Health, supra note 86.

80 Liceuse Cases, supra note 50 , at 592 .

$91 \mathrm{Ibid}$. at 628 .

92 (1821) 19 U. S. (6 Wheat.) 264. 
of lottery tickets, as the Court had held in that case that the state could forbid the sale of such tickets even though their issuance in the District of Columbia and their exportation had been authorized by Congress. There was nothing, however, in that case to show that they were offered for sale in the original packages in which they had entered the state; but neither was there anything to indicate that this was considered important, the test being advanced for the first time eight years later. ${ }^{03}$

The decision ${ }^{94}$ sustaining the power of the states to forbid the sale of intoxicants while still subject to the commerce power of Congress clearly shows that the states were to be as free to apply new conceptions of morality and new theories of public health as those which had the sanction of time. Power to exclude lottery tickets strengthens this conclusion, for long after the adoption of the Constitution lotteries were regarded as desirable, and commerce in their tickets as thoroughly respectable. ${ }^{.5}$ Nor need one be conversant with the Louvre to reahize that the correctness of rulings on the hibidinous character of paintings or books is eminently a question of time, place, and circumstance. The License Cases also expressly rejected the doctrine that the power to prohibit is restricted to articles which cannot properly be said to constitute "subjects of commerce," a concept whicl had been advanced by those judges who accepted the theory that the power of Congress to regulate interstate commerce is exclusive as an excuse for permitting the states to regulate it too. As Taney stated, "spirits and clistilled liquors are universally admitted to be subjects of ownership and property, and are therefore subjects of exchange, barter, and traffic, bike any other commodity in which a right of property exists." "proper subjects of commerce" because of a change in the attitude of the people of a state rather than because of any change in their own intrinsic character.

Safety. Although liquor legislation may be regarded as involving the safety as well as the health and morals of the public, the Court referred to the right "which unquestionably remains, and ought to remain, with the states" to regulate or exclude the importation of gunpowder ${ }^{27}$ as the clearest example of this phase of state authority. Indeed, such laws became so deeply imbedded that Congress, when it tardily regulated the

${ }^{93}$ See Brown v. Maryland, supra note 19.

94 License Cases, supra note 50.

05 The lottery involved in Cohens v. Virginia, supra note 92, had been conducted by the government of the District of Columbia pursuant to an order of the President acting under an act of Congress. The proceeds were used for governmental purposes.

96 Supra note 50, at 577.

97 Marshall, C. J., in Gibbons v. Ogden, supra note 10, at 443. See also, New York v. Miln, supra note 36, at $148,156$. 
packing of nitro-glycerine and allied substances to secure greater safety in course of transportation, provided that nothing in its statute shall "be so construed as to prevent any state, ... city, or town ... from regulating or from prohibiting the traffic in or transportation of those substances, between persons or places ... within their respective territorial limits, or from prohibiting the introduction thereof into such limits, for sale, use, or consumption therein." 98 This act is still in force.

Undesirable Persons. The Constitution" provides, "The Migration or Importation of such Persons as any of the States now existing shall think proper to admit, slall not be prohibited by the Congress prior to the Year" 1808. This limitation properly lias been considered as recognizing that the commerce power of Congress reaches both the migration and the importation of persons. ${ }^{100}$ It constitutes no evidence, however, of a general power in the states over such subjects. Yet the existence of such autlority seems never to have been questioned. On September 16, 1788, one year after Congress submitted the Constitution to the states for ratification, it passed a resolution reading, "Resolved, that it be, and it is hereby recommended to the several states, to pass proper laws for preventing the transportation of convicted malefactors from foreign countries into the United States." 101 Unless this is taken to reflect a fear lest the Constitution be not ratified, it clearly recognized that the states would retain a concurrent power to forbid the inmigration of undesirable persons. Many years later, in sustaining a state law intended to gnard against an influx of persons likely to become public cliarges, the Court held that this power reaclies interstate as well as foreign comnuerce, stating, "We think it as competent and as necessary for a state to provide precautionary measures against the moral pestilence of paupers, vagabonds, and possibly convicts, as it is to gnard against the physical pestilence whicl may arise from unsound and infectious articles." 102 Nine years later we find Justice Woodbury asking, "Who does not know that slaves have been prohibited admittance by many of our States, whether coming from their neighbors or abroad? And which of them cannot forbid their soil from being polluted by incendiaries and felons

0814 STAT. (1866) 82, § 5, 46 U.S. C.A. (1926) \$ 174.

90 U. S. CoNsT., Art. I, $\$ 9, \mathrm{cl} .1$.

100 Marshall, C. J., in Gibbons v. Ogden, supra note 10, at 215-6. And see his opinion, on circuit, in The Wilson v. United States, supra note 7. See also McLean, $\mathrm{J}$., in Passenger Cases, supra note 46, at 401.

10113 Journats of Congress (1801) 142. The resolution was moved by $\mathrm{Mr}$. Baldwin and seconded by Mr. Williainson, both members of the convention which framed the Constitution.

$102 \mathrm{New}$ York v. Miln, supra note 36, at 142. See ibid. at 156. 
from any quarter?"103 Of course, the right to deny admission to diseased persons also was conceded. ${ }^{104}$

One cannot read the decisions of this period without being convinced that it was national, rather than state, power that was in danger at the hands of the Court. Witness Justice Thompson's contention in the Miln case $\mathrm{e}^{105}$ that the right to deny admission to persons of "every description which may be thought to endanger the safety and security of the country ... remains exclusively in the states," and the assertion in the Passenger Cases ${ }^{106}$ that:

“. . . the States have the right to turn off paupers, vagabonds, and fugitives from justice, and the States where slaves are have a constitutional right to exclude such as are, from a common ancestry and country, of the same class of men. And when Congress shall legislate,-if it be not disrespectful for one who is a member of the judiciary to suppose so absurd a thing of another department of the government,-to make paupers, vagabonds, suspected persons and fugitives from justice subjects of admission into the United States, I do not doubt it will be found and declared, should it ever become a matter for judicial decision, that such persons are not within the regulating power which the United States have over commerce. Paupers, vagabonds and fugitives never have been subjects of rightful national intercourse, or of commercial regulations."

It was even denied that Congress could forbid the slave trade, although that is undoubtedly the very power recognized, through qualification, by the clause quoted above. In Groves v. Slanghter ${ }^{107}$ Justice McLean based this conclusion upon the premise that "the constitution acts upon slaves as persons, and not as property." In the Passenger Cases, ${ }^{108}$ wherein he held that the commerce power reaches "persons," he switched to the premise that slaves are to be treated as "merchandise," but without explaining how this could save his conclusion. With the recognition of concurrent power it became unnecessary to indulge in such specious reasoning in order to preserve the state's right to act, so that these precedents have proved no obstacle to congressional regulation of the interstate passage of human beings. ${ }^{109}$ But their value as authority for state power remains unshaken. Indeed, the first serious challenge to the power

103 License Cases, supra note 50, at 629. See $i b i d$. at 576-7, 632; Passenger Cases, supra note 60 , at $423,425,426-8,458,498,520$. Although Groves v. Slaughter, supra note 49 , is cominonly cited as having held that a state may forbid the importation of slaves, the question was not passed upon either in that or any other case.

${ }^{104}$ See supra note 89.

105 Supra note 36 , at 148 .

106 Supra note 46 , at 426 . See $i b i d$. at 466 , where Taney, C. J., dissenting, agreed with this branch of the majority argument.

107 Supra note 49 , at 505 .

108 Supra note 46 , at 406 .

109 See Hoke v. United States (1913) 227 U. S. 308; Caminetti v. United States (1917) 242 U. S. 470; Gooch v. United States (1936) 297 U. S. 124. 
of the states to prohibit interstate commerce, save where their legislation discriminates against such commerce, ${ }^{110}$ came less than fifty years ago when the Court overruled the License Cases.

\section{THE SILENCE OF CONGRESS}

A careful reading of the opinion in Cooley v. Board of Wardens ${ }^{111}$ discloses no intention to alter the existing law. Apparently the Court thought that it was merely explaining and clarifying the rule as thus far developed. Hence, in view of the holding in Peirce v. New Hampshire, ${ }^{112}$ we are forced to conclude that it considered interstate commerce in intoxicants to lend itself to "different systens of regulation, drawn from local knowledge and experience, and conformed to local wants." Obviously the profession accepted a tike conclusion, since it is impossible to explain, on any other ground, the long delay in presenting this issue for reconsideration. There certainly had been no hesitancy in attacking prohibitory liquor laws upon any ground that gave promise of success. ${ }^{113}$ But in 1886 the Court, reversing the Granger Cases, ${ }^{114}$ held that railroad rates for the interstate carriage of goods are not subject to state control..$^{115}$ Other decisions ${ }^{116}$ of the same year gave definite proof that we

110 Railroad Co. v. Husen (1878) 95 U. S. 465 , must be distinguished on this ground, the alleged quarantine being held to constitute an embargo. The Court added, "We unhesitatingly admit that a State may pass sanitary laws, and . . may prevent persons and animals suffering under contagious or mfectious diseases, or convicts, etc., from entering the State . . . "Ibid. at 472 . See also Minnesota v. Barber (1890) 136 U. S. 313; Brimmer v. Rebman (1891) 138 U. S. 78; Voight v. Wright (1891) 141 U. S. 62.

111 Supra note 61.

112 Supra note 50.

113 See, among many, Pierce v. State (1843) 13 N. H. 536; Greene v. Briggs (1852) 10 Fed. Cas. No. 5,764; State v. Snow (1854) 3 R. I. 64 ; People v. Hawley (1854) 3 Mich. 330; State v. Clark (1854) 28 N. H. 176; Commonwealth v. Clapp (1855) 71 Mass. 97; Herman v. State (1855) 8 Ind. 545; Beebe v. State (1855) 6 Ind. 501; People v. Toynbee (1855) 2 Parker Cr. (N.Y.) 329; People v. Gallagher (1856) 4 Mich. 244; Wynehamer v. People (1856) 13 N.Y. 378; State v. Wheeler (1856) 25 Conn. 290; Commonwealth v. Murphy (1857) 76 Mass. 1; State v. Paul (1858) 5 R. I. 185; State v. Allmond (1863) 7 Del. 612; City of Clinton v. Phillips (1871) 58 ㄲl. 102; Bartemeyer v. Iowa (1873) 85 U. S. (18 Wall.) 130; Beer Co. v. Massachusetts (1877) 97 U. S. 25; Mugler v. Kansas (1887) 123 U. S. 623 .

114 Peik v. Chicago \& N. W. R. Co. (1876) 94 U. S. 164, 177-8; Chicago, M. \& St. P. R. Co. v. Ackley (1876) 94 U. S. 179.

115 Wabash, St. L. \& P. R. Co. v. Mlinois (1886) 118 U. S. 557. Three judges dissented.

116 The "equal protection of the laws" clause, previously construed as solely for the henefit of negroes, was suddenly expanded into a shield for corporate privilege. Santa Clara County v. Southern Pacific R. Co. (1886) 11s U. S. 394. Cf. Slaughter-House Cases (1872) 83 U. S. (16 Wall.) 36, 81; Yick Wo v. Hopkins (1886) 118 U. S. 356. In Millet v. People (1886) 117 Ill. 294, 7 N. E. 631, and Godcharles Co. v. Wigeman (1886) $113 \mathrm{~Pa}$. St. 431, 6 Atl. 354, the state courts gave us the first concrete applications of the doctrine that was to blossom as "the new 
were entering upon a new chapter of constitutional history in which even basic concepts were to be open to complete reexamination. Little wonder, then, that the right of the dry states to protect themselves against the interstate liquor traffic was challenged in a case reaching the Court two years later.

The Iowa law forbade any common carrier to bring liquor into the state from any other state or territory "without first having been furnished with a certificate, under the seal of the county auditor of the county to which said liquor is to be transported ...., certifying that the consignee ... is authorized to sell intoxicating liquors in sucl county." In lolding this provision unconstitutional, the majority concluded:117

"The power conferred upon Congress to regulate commerce among the States is indeed contained in the same clause of the Constitution which confers upon it power to regulate commerce with foreign nations. The grant is conceived in the same terms, and the two powers are undoubtedly of the same class and character and equally extensive. The actual exercise of its power over either subject is equally and necessarily exclusive of that of the States, and paramount over all the powers of the States; so that state legislation, however legitimate in its origin or object, when it conflicts with the positive legislation of Congress, or its intention reasonably implied from its silence, in respect to the subject of commerce of both kinds, inust fail... The same inference is not always to be drawn from the absence of congressional legislation. ... The question, therefore, may be still considered in each case as it arises, whether the fact that Congress has failed in the particular instance to provide by law a regulation of coinmerce among the States is conclusive of its intention that the subject sball be free from all positive regulation, or that, until it positively interferes, such commerce may be left to be freely dealt with by the respective States."

Applying this test, they decided that congressional authorization to "every railroad company ... to carry ... all passengers, troops, government supphes, mails, freight, and property on their way from any State to another State, and to receive compensation therefor," 118 and its "silence" relative to the exclusion of any particular articles, "are certainly indications of its intention that the transportation of commodities between the States shall be free, except where it is positively restricted by Congress itself, or by the States in particular cases by the express permission of Congress." 119

The doctrine that "the silence of Congress" may be evidence of its intention that state regulation shall not be enforced was not new to this case, as it can be traced back as far as Marshall. ${ }^{120}$ It is even possible

liberty" under the Fourteenth Ainendinent, remaking the "due process" clause into a substantive rather than merely procedural limitation. For the setting of these cases, see Pound, Liberty of Contract (1909) 18 Yare L. J. 454, and Corwin, Dute Process of Law Before the Civil War (1911) 24 HaRv. L. Rev. 366, 460.

117 Bowman v. Chicago and N. W. R. Co. (1888) 125 U. S. 465, 482-3.

11814 Stat. (1866) 66, Rev. Stat. (1878) § 5258, 45 U. S. C. A. (1926) § 84. 119125 U. S. at 485.

120 Gibbons v. Ogden, supra note 10, at 208-9. And see Story, J., dissenting, in New York v. Miln, supra note 36, at 158. 
that it was one of the pegs upon which the Court hung its holding in the Passenger Cases. ${ }^{121}$ But never before had it been used to block a state in its efforts to make its domestic policies effective by preventing their evasion through a resort to interstate traffic in the forbidden goods. The closing pages of the opinion were even more harsh, as they indicated that silence is always a barrier to state regulation of interstate commerce. In an effort to defend this obviously untenable position, the majority reverted to the pre-Cooley case doctrine that inspection, quarantine, and sanitary laws, forbidding "the introduction into the States of articles of trade, which, on account of their existing condition, would bring in and spread disease, pestilence, and death, such as ... substances infected with the germs of yellow fever or the virus of small-pox, or cattle or meat or other provisions that are diseased or decayed, or otherwise, from their condition and quahty, unfit for human use or consumption," are valid because "Such articles are not merchantable; they are not legitimate subjects of trade and commerce. They may be rightfully outlawed as intrinsically and directly the immediate sources and causes of destruction to human health and life." ${ }^{122}$ This reasoning, in addition to being overrefined, might prevent Congress from passing "inspection, quarantine, ${ }^{123}$ and sanitation" laws; and it was soon expressly rejected ${ }^{124}$ as unsound. Nor could it justify the ruling in the Cooley case, since twice unanimously sustained. ${ }^{125}$ It may not be uncharitable to suggest that the Court was more interested in its conclusion than in the precedents.

Although Bowman v. Chicago \& N.W.R. Co. was concerned solely with importation, the majority added: ${ }^{126}$

"It might be very convenient and useful in the execution of the policy of prohibition within the State to extend the powers of the State beyond its territorial limits. . . . It is easier to think that the right of importation from abroad, and of transportation from one State to another, imcludes, by necessary implication, the right of the importer to sell in unbroken packages at the place where the transit terminates; for the very purpose and motive of that branch of commerce which consists in transportation, is that other and consequent act of coinmerce which consists im the sale

121 Supra note 46, at 399-400: "It has been well remarked, that the regulation of commerce consists as much in negative as in positive action. . . . When this [i.e. state] power is exercised, how can it be known that the identical thing has not been duly considered by Congress?"

122125 U. S. at 489,493 . Cf. supra note 96.

123 The first statute providing a national quarantine system supplementing the state systems had been passed ten years earlier. 20 STAT. (1878) 37. It was not extended to include interstate shipping until 27 STAT. (1893) 450, \& 3, 42 U.S.C.A. (1926) \$ 92. A cattle quarantine act had been passed in 1884. See supra note 83.

124 Compagnie Française de Navigation à Vapeur v. Louisiana State Board of Hcalth (1902) 186 U. S. $380,390$.

125 The James Gray (1858) 62 U. S. (21 How.) 184; Ex parte McNiel (1871)

80 U. S. (13 Wall.) 236.

120125 U. S. at 499. 
and exchange of the commodities transported. . . But it is not necessary now to express any opinion upon the point."

This was an obvious bid for counsel to prepare the way for such a ruling. Naturally they acted at once, so that only two years passed until the decision in Leisy v. Hardin. ${ }^{12 \pi}$ In expressly overruling Peirce v. New Hampshire, ${ }^{128}$ the majority stated:129

"The power vested in Congress ... is co-extensive with the subject on which it acts and ... must be capable of authorizing the disposition of those articles which it introduces. . . A subject matter which has been confided exclusively to Congress by the Constitution is not within the jurisdiction of the police power of the State, unless placed there by congressional action. ... Whenever, ... Congress remains silent, ... the only legitimate conclusion is that the general government intended that power should not be affirmatively exercised, and the action of the States cannot be permitted to effeet that which would be incompatible with such intention. Hence, inasmuch as interstate commerce, consisting in the transportation, purchase, sale and exchange of commodities, is national in its character, and must be governed by a uniform system, so long as Congress does not pass any law to regulate it, or allowimg the States so to do, it thereby indicates its will that such commerce shall be free and untrammelled."

In view of over forty years of acquiescence in the ruling in Peirce $v$. New Hampshire, this interpretation did violence to the "silence" of the national legislature. It was almost immediately corrected by passage of the Wilson Act, ${ }^{130}$ providing that "all fermented, distilled, or other intoxicating liquors or liquids transported into any State [from any otler state, territory, or foreign country] ... shall upon arrival in such State ... be subject to the operation and effect of the laws of such State ... enacted in the exercise of its pohice powers, to the same extent and in the same manner as though such liquids or liquors had been produced in such State ... and shall not be exempt therefrom by reason of being introduced therein in original packages or otherwise." Although sustained, ${ }^{131}$ it was given as narrow an interpretation as possible, being permitted to overrule Leisy v. Hardin but not the Bowman case. Thus the state was held to be powerless to seize hiquor while still in the hands of the public carrier, 132 "upon arrival" being construed to mean "upon

$12 \pi$ (1890) 135 U. S. 100.

128 Supra note 50.

$129135 \mathrm{U}$. S. at 108-110. In an effort to accommodate the precedents, they added that laws constituting "mere aids rather than regulations" are valid. Ibid. at 118. But acts forbidding the importation or sale of lottery tickets, libidinous books or pictures, or slaves, or the immigration of paupers or felons, do not aid commerce; they prohibit it.

13026 STAT. (1890) 313, 27 U.S. C. A. (1926) §121. For a general discussion of the regulation of interstate shipment of imtoxicating liquors as affected by U. S. Const., Amend. XXI, see Note (1937) 25 CaLIf. L. Rev. 718.

131 In re Rabrer (1891) 140 U. S. 545. For an excellent discussion of this case, and of those sustaining the other divesting statutes cited infra, see Bikle, op. cit. supra note 16.

132 Rhodes v. Iowa (1898) 170 U. S. 412 ; Vance v. Vandercook Co. (No. 1) 
delivery to the consignee." Even C.O.D. shipments were sanctioned, ${ }^{133}$ as were deliveries to persons known to the shipper to be "in the habit of becoming intoxicated." 134 This could scarcely have been upon constitutional grounds, as the opinion in Leisy v. Hardin ${ }^{135}$ had conceded that state power, except for conflicting national laws or "silence," reaclies importation. Having forbidden C.O.D. transactions in 1909, ${ }^{136}$ Congress finally enacted the Webb-Kenyon Act, ${ }^{137}$ which was construed to permit the states to prohibit the importation of liquors destined for possession or use in violation of state law. As thus construed, it was sustained..$^{138}$

State legislation prohibiting the sale of oleomargarine and other substitutes for milk products has had a similar history. In 1888 the Court held ${ }^{139}$ that the manufacture and sale of such products may be forbidden for reasons of public health. As the oleomargarine involved in that case was a local product, no question of interstate comnerce was involved. Six years later it sustained a Massachusetts statute forbidding the sale of imported, together with doniestic, oleomargarine not "free from coloration or ingredient that causes it to look hike butter," stating: "It is legislation which 'can be most advantageously exercised by the States themselves." "140 The opinion distinguisled Leisy v. Hardin ${ }^{141}$ on the ground that the beer involved in that case "was what it appeared to be" rather than a "drink colored artifically so as to cause it to look like beer." 142 The dissenting judges felt that protection against fraud in in-

(1898) 170 U. S. 438; Heyman v. Southern Ry. Co. (1906) 203 U. S. 270; Louisville \& N. R. Co. v. Cook Brewing Co. (1912) 223 U. S. 70.

133 American Express Co. v. Iowa (1905) 196 U. S. 113; Adams Express Co. v. Iowa (1905) 196 U. S. 147.

134 Adams Express Co. v. Kentucky (1909) 214 U. S. 218.

135 Sutpra note 127, at 110: ". . . the importation cannot be prohibited without the consent of Congress."

13635 STAT. (1909) $1136, \S 239$, 18 U.S. C. A. (1926) § 389, making such transactions misdemeanors.

13737 STat. (1913) 699, 27 U.S. C.A. (1926) § 122.

138 Clark Distilling Co. v. Western Maryland Ry. Co. (1917) 242 U. S. 311 ; McCormick v. Brown (1932) 286 U. S. 131. In the form in which the bill became law, it would seem to forbid such shipments rather than permit the states to do so. As no penalty was attached, such a construction would render the act nugatory, since there is no general penalty clause in the federal statutes coverimg such cases. Mossew v. United States (C. C. A. 2d, 1920) 266 Fed. 18. The title, "An act divesting intoxicating liquors of their interstate character in certain cases," clearly shows its purpose, and it has been construed accordingly. The phraseology, borrowed from In re Rahrer, supra note 131, at 562, is unfortunate, as Congress cannot deprive commerce of its interstate character. It merely deprives it of the immunity from state control resulting from congressional silence.

130 Powell v. Pennsylvania (1888) 127 U. S. 678. And see McCray v. United States (1904) 195 U. S. 27, 62 ; Magnano Co. v. Hamilton (1934) 292 U. S. 40.

140 Plumley v. Massachusetts (1894) 155 U. S. 461, 479.

141 Supra note 127.

142155 U. S. at 474. 
terstate commerce is as much a federal function as the protection of health and morals through prohibiting interstate commerce in intoxicants, and that in addition existing federal provisions requiring adequate labels "amply protect the public from the danger of being induced to purchase oleomargarine for butter." 143 Although their views did not prevail, when Pennsylvama attempted to apply the act previously sustained as to local products to imports still in their original packages, the Court called a halt. The majority wrote: ${ }^{144}$

"If Congress has affirmatively pronounced the article to be a proper subject of commerce, we should rightly be influenced by that declaration. By reference to the statutes we discover that Congress in 1886 passed 'An act defining butter, also imposing a tax upon and regulating the manufacture, sale, importation and exportation of oleomargarine.'145 . . . This act shows that Congress ... recognized the article as a proper subject of taxation and ... traffic. ... 'Whatever our individual views may be as to the deleterious or dangerous qualities of particular articles, we cannot hold that any articles which Congress recognizes as subjects of interstate coinmerce are not such."

Congress thereupon passed "An act to make oleomargarine and other imitation dairy products subject to the laws of any State ... into which they are transported," their former immunity being lost "upon the arrival within the himits of such State." ${ }^{146}$ The validity of this statute, which is still in force, seems never to have been questioned.

Since these two rapid reversals, the Court naturally has been more hesitant to construe congressional "silence" to impede state action. This has been true even where Congress has expressly occupied a part of the field. In Reid v. Colorado, ${ }^{147}$ holding that a national quarantine against cattle known to be diseased does not prevent a state from denying admission to cattle actually diseased or reasonably suspected of being so, the Court seems to have reversed the presumption resulting from silence, stating: "It should never be held that Congress intends to supersede or by its legislation suspend the exercise of the police powers of the States, ... unless its purpose to effect that result is clearly manifested." 148 The newer attitude is also reflected in Crossman v. Lurman ${ }^{140}$ and Savage $v$.

143 Ibid. at 481.

144 Schollenberger v. Pennsylvania (1898) 171 U. S. 1, 8-9, 13. The last sentence was quoted from Leisy v. Hardin, supra note 127 , at 125 . They distinguished the Plumley case, supra note 140 , on the ground that "silence" cannot be construed to permit interstate traffic in "adulterated and therefore unhealthy or impure" products. Loc. cit. supra, at 13. The minority, not willing to accept the ruling in Leisy v. Hardin, insisted that a legislature is justified in treating "unadulterated" oleomargarine as just as "unhealthy" and "impure" as the colored product.

14524 STAT. (1886) 209.

14632 STAT. (1902) 193, § 1, 21 U.S. C. A. (1926) § 25.

147 (1902) 187 U. S. 137.

148 Ibid. at 148.

149 (1904) 192 U. S. 189. 
Jones, ${ }^{150}$ sustaining state pure food laws supplementing existing federal statutes. In the latter case Justice (now Chief Justice) Hughes, speaking for an unanimous bench, said: ${ }^{151}$

"The intent to supersede the exercise by the State of its police power as to matters not covered by the Federal legislation is not to be imferred from the mere fact that Congress has seen fit to circumscribe its regulation and to occupy a limited field. In other words, such imtent is not to be implied unless the act of Congress fairly interpreted is in actual conflict with the law of the State."

Perhaps the best example of this more liberal attitude toward state prohibition of interstate trade is furnished by the game law case, Silz $v$. Hesterberg. ${ }^{152}$ The Leisy and Schollenberger cases had prompted Congress to pass the Lacey Act, ${ }^{153}$ section five of which provides: "All dead bodies, or parts thereof, ... of any wild game aninials, or gaine or song birds transported into any State ... shall upon arrival in such State ... be subject to the ... laws of such State ... enacted in the exercise of its police power ...." The Court virtually held this statute to be superfluous, as it sustained the right of a state, "independent of any authorization thereof by the Lacey Act," 154 to forbid possession as well as sale of game, whether killed within the state or inported from another state or country, during the closed season. Its statement that "The purpose of the law is not to regulate interstate commerce, but by laws alike apphcable to foreign and domestic game to protect the people of the State in the right to use and enjoy the game of the State," 155 is scarcely convincing. Unless the Court abandons the rule that the right to import carries with it the right to possess, and even to sell-a step it has not taken ${ }^{150}$ and is not likely to take, for reasons pointed out below-such statements must remain hollow phrases. As much, or more, could have been said for the laws nullified in any of the liquor cases.

The only field in which the negative presumption of the liquor cases has been applied of late ${ }^{157}$ is that where the harm results froin economic

150 (1912) 225 U. S. 501.

$151 \mathrm{Ibid}$. at 533. Cf. McLean, J., in Passenger Cases, supra note 46, at 400: "When this power is exercised, how can it be known that the identical thing has not been duly considered by Congress?"

162 (1908) 211 U. S. 31, aff'g People v. Hesterberg (1906) 184 N. Y. 126, 76 N. E. 1032.

15331 StaT. (1900) 188, §5, 18 U.S.C.A. (1926) § 395.

154211 U. S. at 44.

155 Ibid. at 43 .

156 "The protection accorded to this commerce by the Federal Constitution extended to the sale by the receiver of the goods in the original packages." Savage v. Jones, supra note 150, at 520. And see Baldwin v. Seelig, supra note 5; McDermott v. Wisconsin (1913) 228 U. S. 115.

167 Although Oregon-Washington R. Co. v. Washington (1925) 270 U. S. 87, held that passage of the Plant Quarantine Act of 1912, 37 STAT. (1912) 315, 7 U.S.C.A. (1926) $\$ 161$, constituted notice to the states to vacate this field, this 
factors connected with the production of the goods rather than from the character of the goods themselves. This brings us to the final phase of our problem. Before turning to it, it will be wise to go back to the Bowman and Leisy opinions to examine one aspect which we have omitted, and which seems to have been overlooked by commentators in general. To be sure, those opinions narrowed the immediate scope of state power to prohibit commerce. Actually, however, they greatly enlarged the potential scope of that power.

\section{THE MEANING OF "EXCLUSTVE"}

There can be little if any doubt that the opinion in Cooley v. Board of Wardens used the phrase "exclusive national power" in the only sense in which a correct use of English permits, i.e., a power which cannot, under any circumstances short of constitutional amendment, be exercised by a state. It is just as certain that this was not the meaning attached to the phrase in the Bowman case. Therein, when the Court spoke of the "actual exercise" of national power as "exclusive," it apparently had nothing more in mind than national supremacy: the federal law being "the supreme law of the land," conflicting "state legislation, however legitimate in its origin ..., must fail." 158 This is the description of a concurrent, rather than an exclusive, power. The stress laid upon the conflicting nature of the state and national policies-the latter imphed from "silence"-renders it doubtful if we can even go so far as to conclude that the Court intended to close the door against the coordinate exercise of state and national powers. If it did, its conclusion has been overruled by later hquor cases $^{159}$ sustaining coordinate laws prohibiting the same acts of importation.

The same confusion is even more noticeable in Leisy v. Hardin: $:^{180}$

"A subject matter which has been confided exclusively to Congress by the Constitution is not within the jurisdiction of the police power of the states, unless placed there by congressional action. . . .

was upon the assumption that Congress bad occupied tbe whole of it. This ruling was corrected by 44 STAT. (1926) 250, 7 U.S.C.A. (1926) §161, providing that even federal inspection and approval does not exempt plants from state laws.

158 Supra note 117 . See the quotation given at that point. As Taney, C. J., pointed out in the License Cases, supra note 50, at 581-2, this confusing use of "exclusive" has been indulged in from the very first. It has persisted to the present day. See Grant, op. cit. supra note 16.

159 Compare the state laws sustained in the cases cited sitpra note 138 with the Reed Amendment, 39 STAT. (1917) 1069, 18 U.S.C.A. (1926) \& 341, sustained in United States v. Hill (1919) 248 U. S. 420, and Williams v. United States (1921) 255 U. S. 36. This amendunent was repealed by 49 STAT. (1936) 1930, \& 9, 27 U. S. C.A. (1936 Supp.) \$226. For other instances of coordinate regulation of commerce, see Grant, op. cit. supra note 16, at 1019-23. 160 Supra note 127, at 108, 109-10, 119. 


\begin{abstract}
"Inasmuch as interstate commerce, consisting in the transportation, purchase, sale and exchange of commodities, is national in its character, and must be governed by a uniforn system, so long as Congress does not pass any law to regulate it, or allowing the states so to do, it thereby indicates its will that such commerce shall be free and untrammelled. . . . The importation cannot be prohibited without the consent of Congress. . .

"As the grant of the power to regulate commerce among the states, so far as one system is required, is exclusive, the states cannot exercise that power without the assent of Congress."
\end{abstract}

Obviously, this is a very different word than that spelled with the same letters in Cooley v. Board of Wardens, where the Court was careful to point out: ${ }^{161}$

"If the states were divested of the power to legislate on this subject by the grant of the commercial power to Congress, it is plain this act could not confer upon them this power to legislate. If the Constitution excluded the states from making any law regulating commerce, certainly Congress cannot regrant, or in any manner reconvey to the states that power."

Thus in the very act of expanding the rule that "Whatever subjects ... are in their nature national, or admit only of one uniform system, or plan of regulation, ... require exclusive legislation by Congress," to include the whole field of interstate commerce, the Court redefined exclusive to mean concurrent, but with a presumption against state action in the face of congressional silence. This annihilated the Cooley rule as a doctrine of constitutional law and remade it into a test of legislative intent. It left no constitutional barrier to prevent Congress, by breaking its silence, -or the Court, by refusing to draw a negative presumption therefromfrom giving free rein to state laws prohibiting the importation or sale of articles which the respective states consider undesirable. Nevertheless, it was somewhat surprising to have the Court hand down its first landmark decision sustaining a prohibition based purely upon economic grounds in a state, rather than national, case.

\title{
ECONOMIC HARM
}

The Fourteenth Amendment forbids any state to "deny to any person within its jurisdiction the equal protection of the laws." This merely gives constitutional mandate to a principle which should guide legislation even in the absence of bills of rights and judicial review. The nation, no less than the state, should accord equal treatment to all who are similarly circumstanced. Given the thesis that "in commerce we are one people," with "free trade among the states," it would seem to follow that neither the domestic nor the extra-state producer should be given advantages as against the other. If dealers in goods from other states are not to be discriminated against, neither should they be given privileges

161 Supra note 61 , at 318 . And see Gibbons v. Ogden, supra note 10 , at 202 ; In re Rahrer, supra note 131 , at $\mathbf{5 6 0}$. 
which those handling local products do not enjoy.

This principle is difficult to apply in a federal system. Were a state to deny to factories in the western half of a city the privilege of exploiting child labor, or of sweating adult labor through long hours and low wages, yet permitting these things to be done by factories located in the eastern half of the city, while at the same time granting all complete freedom to sell their products throughout the state and to compete for the markets of other states, there can be no doubt as to the ruling of the Court or its popularity. Yet this is what may lappen in fact, where a state line divides the city. As long as the American domestic ${ }^{102}$ scene, particularly in its judicial aspects, ${ }^{103}$ was dominated by Spencerian liberalism, which left all such questions to the free play of economic factors, there was no place in our internal program for such legislation. With the triumph of "labor legislation" in the closing days of the last and opening of the present century, it became evident that this would not be so for long. The Olio Legislature's petition ${ }^{104}$ to Congress, stating:

"Whereas the blot of unrestricted-or practically unrestricted-child labor still rests upon a number of states, the youth and future career of the Nation's embryo citizens being sacrificed to the assumed needs of commerce; and

"Whereas the reckless waste of future potentiality involved in the industrial exploitation of immature children is uneconomic and wrong and constitutes a crime against childhood and against the race itself; and

"Whereas the products of various industries of the State of Ohio, manufactured under humane conditions and without robbing childhood of its birthright, are forced to seek a market in competition with the output of child-labor industries in various states in the Union; ..."

and requesting passage of a national statute closing the interstate market to child-labor products, was an inevitable consequence. Reliance upon national legislation, resulting in the passage of the Clitld Labor Act of $1916,{ }^{165}$ was rendered still more certam by the fact that state legislation dealing with prison-made goods had resulted in state decisions antagonistic to state power, at least in the face of congressional "silence."

Convict Labor. We are agreed today that children do not benefit from being drawn into the productive process at a tender age, and that society suffers when this is permitted. The only persons to gain are the manufacturers who exploit this clieap labor market, and the parents who appropriate its paltry earnings. When we turn to prison labor we are

162 In economic matters, we have bifurcated mimds. Spencerian liheralism never has played an important role in our foreign trade program.

163 See the article by Pound, supra note 116.

16453 CoNG. REc. (1916) 1002. The Massachusetts Legislature presented a similar one. 45 Cong. Rec. (1910) 5245.

16539 Stat. (1916) 675. 
faced with an entirely different set of facts. There can be no doubt that convicts benefit from being engaged in productive enterprises, and that society benefits from having them employed. But free labor finds it just as impossible to compete with prison labor as if such labor were socially undesirable. The most satisfactory compromise has seemed to be a program of state use. Although this still deprives free labor of a portion of its normal market, it ends price competition, which has proved to be the most demorahizing factor accompanying the sale of prison-made goods on the open market.

Faced with interstate competition, such a program was merely a cul de sac. Although a state might withdraw the products of its own prisons from public sale, its markets were still flooded with prison-made goods from other states. Department of Labor surveys ${ }^{166}$ showed that the greater part of all such goods were manufactured for other than the domestic market. This is the type of sisterly love reflected by the still current police practice of releasing undesirable persons with the understanding that they will lend the pleasure of their company to some other community. The obvious way out was to put an end to this traffic. Could the states do this?

The rule of the Bowman and Leisy cases seemed to present an insuperable obstacle to state laws in the absence of express congressional authorization. The Ohio court so held in $1897,{ }^{167}$ to be followed a year later by a New York decision in which a closely divided court ruled against so gentle an act as one requiring that all convict-made goods be labelled as such. Placing its decision upon the broadest ground possible, the court wrote: "The state where labor commands the highest price, cannot make discriminating regulations for the sale of the goods made in the state where it is cheapest in order to favor the interests of its own workmen." 168 This decision was reaffirmed in $1910 .{ }^{169}$ Two years later the Massachusetts court, in an advisory opinion, ${ }^{170}$ ruled:

"Goods made by convicts are lawful subjects of commerce. . . . Plainly the purpose of the bill is to affect the availability and attractiveness in the market of the branded or labelled goods. There is nothing wrong in the

166 U. S. Bureau of Labor Statistics, Bulletin No. 372 (1925) 14; ButreTIN No. 595 (1933) 26.

167 Arnold v. Yanders (1897) 56 Ohio St. 417,47 N. E. 50. The act discriminated against extrastate goods, but the court chose to rest its opimion upon the broader ground.

168 People v. Hawkins (1898) 157 N. Y. 1, 16, 51 N. E. 257, 261. An earber act requiring that "all goods . . . made by convict labor . . . im any state, except the State of New York, . . . be branded . . . 'convict made," " had been held unconstitutional on the ground of discrimination. People v. Hawkins (1895) 92 N.Y. Supr. Ct. 43, 32 N. Y. Supp. 524.

169 People v. Raynes (1910) 198 N. Y. 622, 92 N. E. 1097. The goods involved in this case were no longer in their origimal packages. See People v. Raynes (1910)

136 App. Div. 417, 422, 120 N. Y. Supp. 1053, 1056.

170 Opinion of the Justices (1912) 211 Mass. 605, 607, 98 N. E. 334, 336. 
nature of things in prison-made goods. . . Such goods are not unsanitary or so inferior in quality that their sale would constitute a fraud on the public. ... Differences in grade of workmanship, if there are any, would be as apparent without branding as in like products made in private shops."

When even labelling acts were held to impose unlawful burdens upon interstate commerce, it was evident that the courts would not sustain an embargo. Hence, starting at least as early as $1911,,^{171}$ the issue was carried to Congress, culminating in passage of the Hawes-Cooper Act ${ }^{172}$ in the closing days of the Coolidge administration. In order to allow a fiveyear period during which states then dependent upon the export market could rearrange their prison-labor set-up, the act provided that it should become effective on January 19, 1934. Since the Child Labor Act bad been held unconstitutional, ${ }^{173}$ the Hawes-Cooper Act is a divesting statute rather than a prohibiting one. It is from the different treatment accorded these two statutes that we must derive the present rules of law.

The Child Labor Case. In 1895 Congress enacted that the interstate transportation of lottery tickets or of certain information concerning lotteries is a felony. The title of the act, ${ }^{174}$ no less than its contents, revealed its purpose to aid in suppressing the lottery traffic. When its validity was questioned eight years later, James M. Beck, as attorney for the governinent, presented an able argument ${ }^{175}$ in which he reasoned: "The power ... vested in the United States was the power of each constituent state over its external relations, and in its transfer to the federal government it was in no respect diminished, except by certain express limitations .... With these minor limitations the delegated power was as exhaustive and plenary as that which it was intended to supercede .... The most familiar exercise of the power to regulate commerce in the minds of the men who framed the federal Constitution was, doubtless, the total or partial prohibition of traffic in particular articles." Although he convinced all nine judges that the interstate traffic in sucli tickets can be prohibited, four insisted that the power to do this still rests exclusively with the states. Accepting the doctrine that commerce is primarily transportation, ${ }^{176}$ they concluded that the power to "regulate conımerce"

171 U. S. BUREaU OF Labor Statistics, Butietin No.' 616 (1936) 704.

17245 STAT. (1929) 1084, 49 U.S. C. A. (1936 Supp.) $\$ 60$.

173 Hammer v. Dagenhart (1918) 247 U. S. 251.

174 "An Act For the suppression of lottery traffic through national and interstate commerce and the postal service subject to the jurisdiction and laws of the United States," 28 STAT. (1895) 963, 18 U.S. C. A. (1926) \$387. An earlier act restricted to transportation by mail had been sustained in In re Rapier (1891) 143 U. S. 110 .

175 The quotations which follow are taken from his argument as digested in the official report of Champion v. Ames (1903) 188 U. S. 321, 336, 341.

176 Time changes all things. The first commerce clause case, Gibbons v. Ogden, supra note 10, arose out of a refusal to concede that commerce so much as includes transportation! 
is merely one to keep the channels of trade open, and not to protect the citizen against undesirable types of commerce. The only articles or persons, the transportation of which they were willing to concede might be forbidden by Congress, are those which inay endanger other articles or persons during the course of transportation. ${ }^{177}$ The majority, however, took a broader view, saying: ${ }^{178}$

\footnotetext{
"Can it be possible that it must tolerate the trafic, and simply regulate the manner in which it may be carried on? Or may not Congress, for the protection of the people of all the States, . . . drive that traffic out of commerce among the States? ... As a State may, for the purpose of guarding the morals of its own people, forbid all sales of lottery tickets withm its limits, so Congress, for the purpose of guarding the people of the United States against the 'widespread pestilence of lotteries' and to protect the commerce which concerns all the States, may prohibit the carrying of lottery tickets from one State to another."
}

This decision soon developed a following, ${ }^{179}$ the Court sustaining every national statute prohibiting interstate commerce which caine before it during the next fourteen years. But in 1918, again by a five to four vote, it threw out the Child Labor Act passed two years previously. The majority apparently accepted the basic premise of the dissenting judges in the Lottery Case as sound, as they stated: "The power is one to control the means by which commerce is carried on, which is directly the contrary of the assumed right to forbid commerce from moving and thus destroy it as to particular commodities." 180 But as they were unwilling

177 In an effort to justify national quarantine laws, they wrote: "The power to prohibit the transportation of diseased annnals and infected goods over railroads or on steamboats is an entirely different thing, for they would be in themselves injurious to the transaction of interstate commerce, and, moreover, are essentially commercial in their nature. And the exclusion of diseased persons rests on different ground, for nobody would pretend that persons could be kept off the trains because they were going from one State to another to engage in the lottery business." Champion v. Ames, supra note 175, at 374. Compare the earlier contention, supra note 122 , that the states can pass quarantine laws because diseased or putrid articles "are not legitimate subjects of trade and commerce." The argument also disregards the fact that the imjury from decayed food, like that from misbranded substances, comes in the eating and not in the carrying.

$178188 \mathrm{U}$. S. at $355,357$.

179 Hipohite Egg Co. v. United States (1911) 220 U. S. 45; Hoke v. United States (1913) 227 U. S. 308; McDermott v. Wisconsim (1913) 228 U. S. 115; Hanish v. United States (C. C. A. 7th, 1915) 227 Fed. 5S4, cert. den., (1915) 239 U. S. 645; Seven Cases of Eckman's Alterative v. United States (1916) 239 U. S. 510; Caminetti v. United States (1917) 242 U. S. 470 . Clark Distilling Co. v. Western Maryland Ry. Co., supra note 138, clearly foreshadowed the ruling in the Hill and Williams cases, supra note 159, that Congress can forbid the interstate transportation of imtoxicants. For later cases, see Oregon-Washington R. Co. v. Washington, supra note 157; Brooks v. United States (1925) 267 U. S. 432; Thornton v. United States (1926) 271 U. S. 414; Carter v. United States (C. C.A. 5th, 1930) 3S F. (2d) 227, cert. den., (1930) 281 U. S. 753. The anti-trust cases are discussed infra.

180 Hammer v. Dagenhart (1918) 247 U. S. 251, 269-70. While purporting to be an interpretation of a quotation from Marshall, this statenient does violence to 
to overrule that case and the others which had followed it, they gave us a new rule: the power of Congress to prohibit commerce is restricted to instances in which the harm occurs during or after transportation. It cannot apply where "the goods shipped are of themselves harmless," 181 since this would invade the reserved power of the states to regulate production.

The opinion evaded the embarrassing fact that the control of consumption, equally with production, is a state and not a national power. Nor did it take into account previous decisions sustaining the exclusion of so-called "harmless" goods from the interstate market. Trust-made goods are no more harinful "of themselves" than those made in highly competitive industries, ${ }^{182}$ yet the whole framework of anti-trust acts has been erected upon the commerce power. The Commodities Clause, ${ }^{183}$ in language virtually identical to that of the Child Labor Act, forbids any railroad company "to transport from any State . . . to any other State ... any article or commodity ... in which it may have any interest direct or indirect." Its necessary effect was to nullify the policy which Pennsylvarnia had followed for generations with reference to combination between coal-producing and coal-carrying companies, yet it was sustained. ${ }^{184}$ More sigmificant is the fact that the new rule was a purely artificial one, and can only be explained on the nuajority's hesitancy to turn back while refusing to go forward. In the case of child-labor products, no less than that of intoxicating hquors, evil does follow transportation, for "transportation encourages the evil" and causes it to spread to other states. Reduced to its true meaning, the new rule was nothing more than a bald statement that economic harm cannot justify federal action. Since even here the anti-trust laws and the Commodities Clause constitute exceptions, we inust narrow the rule still further to the sinple one that the nation must not attempt to influence labor standards.

Although the majority had started with the same premise that had been used by the minority in the Lottery Case, they thus reached a very different conclusion. The difference is far more basic than we have noted. The 1903 judges had defended the exclusive right of the importing state to regulate its own affairs. Why should it not be free to accept or reject lottery tickets, as it might see fit? But there is no such underlying thesis in the Child Labor opinion. Congress was held to have trespassed upon

Marshall's concept of the commerce power.

181 Ibid. at 272.

${ }^{182}$ See the argument of counsel in United States v. American Tobacco Co. (1911) 221 U. S. 106, 132-3.

18334 STAT. (1906) 585, 49 U.S.C.A. (1926) § 1, (8).

184 United States v. Delaware \& Hudson Co. (1909) 213 U. S. 366; United States v. Delaware, L. \& W. R. Co. (1915) 238 U. S. 516. 
the reserved powers of the states; but the Court was thinking of the states as exporters rather than as importers. Congress cannot forbid the transportation of child-labor products from North Carolina to Ohio because to do so is to regulate production in North Carolina. If this is the effect of a congressional embargo, it is equally the effect of an Ohio one. ${ }^{185}$ Ohio cannot regulate production in North Carolina. Q. E. D.

This was really a most startling result; as startling, perhaps, as any ever accomplished under the Tenth Amendment. ${ }^{186}$ Stated plainly, it held that the reserved powers of North Carohina are encroached upon if that state cannot have a market for some of its goods in other states. Yet at no time prior to the adoption of the Constitution did North Carolina possess power to grant its products any safe conduct beyond its borders. In this regard it was entirely at the mercy of its neighbors. The decision held, in effect, that the Constitution not only divided the powers of government between the nation and the states, but also redistributed them as between the states themselves. North Carolina, rather than Congress, was given the former Olio power to protect Ohio citizens from "the competition that kills."

Although from time to time various decisions have whittled at the edges of this doctrime, ${ }^{187}$ it seems to have been accepted, obiter, as recently as 1935.188 The first clear challenge came the following year, when an unanimous bench held that Ohio may forbid the sale of "original packages" of shirts because the Alabama factory had employed convict labor in their manufacture.

185 It will be noted that I do not assert, as others have, that the state law would be invalid because it would "invade the field of Congress' power to regulate interstate commerce." The whole burden of this paper is that the states may, and do, regulate such commerce. Rather, under the doctrine of this case it would not be a regulation of commerce at all, but an invasion of the exporting state's power to regulate production.

186 For its closest rivals, see United States v. Butler (1936) 297 U. S. 1, 68, discussed in Grant, Commerce, Production, and the Fiscal Powers of Congress (1936) 45 Y AIE L. J. 991, 1009-12, and Ashton v. Cameron County Water Improvement District No. One (1936) 298 U. S. 513. Professor Powell explains that the reason this Amendment lends itself to loose thinking is that "It brings to play loose conceptions with balos over them, and thereby confuses the mind in dealing with the genuine issue in the case." Powell, The Child Labor Law (1918) 3 So. L. Q. 175, 189.

${ }^{187}$ See Corwm, Congress Power to Prohibit Commerce (1933) 18 CoRN. L. Q. 477.

188 Baldwin v. Seelig (1935) 294 U. S. 511, 524. Holding that New York cannot forbid the sale of inilk because it was purchased in Vermont for less than the "pegged" minimum price for wholesale purchases in New York, the opinion added: "The next step would be to condition importation upon proof of a satisfactory wage scale in factory or shop, ... One state may not put pressure of that sort upon others to reform their economic standards." 
The Convict Labor Cases. The Hawes-Cooper Act ${ }^{180}$ provides:

"All goods . . . manufactured, produced, or mined, wholly or in part, by convicts or prisoners, except ... on parole or probation, ... transported into any state ... shall upon arrival and delivery in such state . . . be subject to ... the laws of such state ... to the same extent . . . as though ... manufactured, produced, or unined im such state ..., and shall not be exempt therefrom by reason of being mtroduced in the original package or otherwise."

As the act was passed in 1929, but did not go into effect until 1934, one might expect that its constitutional validity would have been settled during the five year waiting period. Alabama's effort to contest it, however, had been thrown out ${ }^{180}$ on various grounds, among them that of prematurity. This defect in American procedure ${ }^{101}$ largely nullified the value of the five year warming, and the act became law with no intimation from the Court as to its probable ruling, and with serious doubts as to the statute's ability to withstand judicial scrutiny being expressed by legal writers. ${ }^{192}$

Alabama chose to "stand on her rights" under the Child Labor Case, and continued to send her prison products to other states. She won a trifling victory in Wisconsin, where the state supreme court held ${ }^{103}$ the state law invalid because it discriminated against goods from other states. She lost in Ohio. ${ }^{194}$ In sustaining this decision, Justice Sutherland, on behalf of an unanimous Court (Justices Van Devanter, McReynolds, and Stone concurring "in the result"), presented a rather brief opinion. $\mathrm{He}$ wrote: ${ }^{195}$

"The view of the State of Ohio that the sale of convict-made goods in competition with the products of free labor is an evil finds anple support in fact and in the similar legislation of a preponderant number of the other states. . . . All such legislation, state and federal, proceeds upon the view

189 Supra note 172.

190 Alabama v. Arizona et al. (1934) 291 U. S. 286.

101 Compare the Austrian plan, under which any statute alleged to violate the division of powers may be contested by the aggrieved government, state or national, in an action im which the government whose statute is attacked becomes the party defendant. Such actions are frequently brought before the statute goes into effect. See Grant, Judicial Review of Legislation Under the Austrian Constitution of 1920 (1934) 28 Am. Pox. Sct. Rev. 670; Austriar Const. (1934) art. 163. Cf. the Canadian substitute sustained in Attorney-General of Ontaric v. Attorney-General of Canada [1912] A. C. 571.

192 See Notes (1925) 25 CoL. L. Rev. 814, 819; (1936) 49 Harv. L. REv. 466, 469 ; Legis. (1936) 21 CoRN. L. Q. 357, 365; (1931) 44 HARv. L. REv. 846, 848; (1930) 23 LAWYER \& BANKER 296.

193 State v. Whitfield (1934) 216 Wis. 577,257 N. W. 601 . The statute merely required labels.

194 Whitfield v. State (1935) 129 Ohio St. 544, 196 N. E. 164, sustaining (1935) 49 Ohio App. 530, 197 N. E. 605. Montana's brief in Alabama v. Arizona et al., supra note 190, quotes a similar opinion handed down by a New York trial court in January, 1932.

105 Whitfield v. Ohio (1936) 297 U. S. 431, 439. 
that free labor, properly compensated, cannot compete successfully with the enforced and unpaid or underpaid convict labor of the prison."

This disposed of the contention that the act violates due process of law, and at the same time (if there be any difference) established the existence of an evil in Ohio, and therefore following transportation. This made it unnecessary to distinguish the Child Labor Case, where the evil, the Court had said, precedes transportation; ${ }^{196}$ although it is painfully obvious that by merely transposing a few words, all that the Court said here would be equally true as to child-labor products. But although counsel had stressed their argument that "the goods shipped are of themselves harmless," one looks in vain for any answer to this branch of the Child Labor decision. Instead, the opinion, without so much as mentioning that case, reasoned:197

"When the goods were sold, their transportation bad come to an end; and the regulative power of the state had attached, except so far as that power might be affected by the fact that the packages were still unbroken. But any restrictive influence which that fact otherwise might have had upon the state power was completely removed by Congress, if the HawesCooper Act be valid. That act is in substance the same as the Wilson Act with respect to intoxicating liquors, ... Each statute simply permits the jurisdiction of the state to attach immediately upon delivery, whether the importation remain in the original package or not. In other words, the importation is reheved from the operation of any rule which recognizes a right of sale in the unbroken package without state interference. . . .

"... The proposition is not contested that the Ohio statute would be unassailable if made to take effect after a sale in the original package. And the statute as it now reads is equally unassailable, since Congress has provided that the particular subjects of interstate cominerce here involved 'shall be governed by a rule which divests them of that character at an earlier period of time than would otherwise be the case,' In re Rahrer, 140 U. S. 545, 562, namely, upon arrival and delivery.

"If the power of Congress to remove the impediment to state control presented by the unbroken-package doctrine be limited in any way (a question which we do not now find it necessary to consider), it is clear that the removal of that impediment in the case of prison-inade goods must be upheld for reasons akin to those which moved this court to sustain the validity of the Wilson Act."

These quotations, which constitute all that was said on this point, are nierely a profession of faith. Substantiating argument is lacking. The opinion simply assumes, as self-evident, that prison-made goods are to be treated the same as intoxicants, the fact that "the goods shipped are of themselves harmless" being of no inportance. It is submitted that this is the proper view, once it is conceded that harm follows transportation. Obviously, harm does follow transportation wherever harm is done to the importing state.

190 No doubt legal evolution was influenced by the fact that the question was reopened in a prison labor case, where it is impossible to say that the injury occurs in course of manufacture because $n o$ injury occurs at that point.

107297 U. S. at $438-41$. 
If this branch of the opinion stands, the Child Labor Case is doomed. The liquor cases give us the key to the evolutionary process whereby this will be brought about. The Wilson Act, consenting to state laws forbidding sale, was followed by the Webb-Kenyon Act, which was construed to permit the states to prohibit importation. This was soon expanded, througl the Reed Amendnent, into a national prohibition of interstate transportation. Congress, jumping over the intermediate step, proceeded at once to the third in regard to prison-made goods. A 1935 statute $^{108}$ provides:

"§ 1. It shall he unlawful for any person knowingly to transport or cause to be transported ... any goods . . manufactured, produced, or mined wholly or in part by convicts or prisoners (except convicts or prisoners on parole or probation), or in any penal or reformatory institution, from one State ... into any State ... where said goods . . . are intended by any person interested therein to be received, possessed, sold, or in any inanner used, either in the original package or otherwise in violation of any Iaw of such State. ...

"§3. Any person violating [the above] shall ... be punished by a fine ... and such goods ... shall be forfeited to the United States. . . ."

The next and final step, also sustained in the liquor cases, will be for Congress to set its own policy rather than hinge its act upon those of the respective importing states.

Althougl in many ways such an act as that involved in this final step would leave a greater freedom of choice to the states than the present setup, ${ }^{199}$ Congress chose to follow Culbertson in using the "approachforcing" systen. In addition to the Whitfield quotation agreeing that economic evils arise from the sale, those defending the law had the argument that the goods were destnied for use in connection with criminal activities in that they were intended to be sold in violation of a valid state law. ${ }^{200}$ There was no escape from the conclusion that "the use of

198 Ashurst-Sumners Act, supra note 2. Section 2, 49 U.S.C.A. (1936 Supp.) $\S 62$, requires all packages containing convict-made goods transported in interstate or foreign commerce to be "plainly and clearly" marked, so that the name and address of the shipper, the name and address of the consignee, the nature of the contents, and the name and location of the penal or reformatory institution where produced . . . may be readily ascertained on an inspection of the outside of such package." This will assist both the national and state governments in enforcing their prohibitory acts.

199 Under the Hawes-Cooper Act the state must forbid the sale of the products of its own prisons in order to close its markets to the prison-made goods of other states. A national embargo against interstate traffic in such goods would leave the state free to follow any domestic program it prefers. The present rule has worked unexpected hardships in the transition from public sale to state use that might not have arisen under such a law. See Bennett, American Prisons-Houses of Idleness (1935) 71 SURVEY 99; Lerrigo, Prisoners Must Work (1936) 72 SURVEY 194; Prison Industries Reorganization administration, Prison Labor Problem in MARYLAND (1936).

200 This argunent was used to good advantage in the Brief for the United 
interstate transportation was necessary to the accomplishment of "this harmful result. Forced to choose between sustaining this statute or making a sliambles of the law, the Court unanimously chose the former. In an opinion by the Chief Justice, it stated: ${ }^{201}$

"By the Act now before us, the Congress purports to establish a rule governing interstate transportation, which is unquestionably interstate commerce. ... . We have frequently said that in the exercise of its control over interstate coinmerce, the means employed by the Congress may have the quality of pohice regulations. . . .

"The contention is inadmissible that the Act of Congress is invalid merely because the horse collars and harness which petitioner manufactures and sells are useful and harmless articles. ...

"Congress may prevent interstate transportation from being used to bring into a State articles the traffic in which the State has constitutional authority to forbid, and has forbidden, in its internal commerce. . . .

"The pertinent point is that where the subject of coinmerce is one as to which the power of the state may constitutionally be exerted by restriction or prohibition in order to prevent harnful consequences, the Congress may, if it sees fit, put forth its power to regulate interstate commerce so as to prevent that commerce from being used to impede the carrying out of the State policy.... The Congress in exercising the power confided to it by the Constitution is as free as the States to recognize the fundamental interests of free labor."

These quotations must not be taken as supporting the doctrine that the authority of the states is primary, and that the power of Congress is restricted to aiding the states in carrying out their programs. As the Court once stated ${ }^{202}$ in regard to intoxicants, "Congress may exercise this authority in aid of the policy of the State, if it sees fit to do so. It is equally clear that the policy of Congress acting independently of the States may induce legislation without reference to the particular policy or law of any given State ... . The control of Congress over interstate coinmerce is not to be limited by State laws." The same view is clearly asserted in the Kentucky Whip and Collar Co. case as to convict-made goods, the opimion stating: ${ }^{203}$

"The Congress ... has not acted on any assumption of a power enlarged by virtue of state action. . . The Congress has formulated its own policy and established its own rule. The fact that it has adopted its rule in order to aid the enforcement of valid state laws affords no ground for constitutional objection."

If Congress can formulate its own policy, it can prohibit the interstate transportation of convict-made goods even where the potential importing state desires to receive them. This being so, and the power being

\footnotetext{
States as Amicus Curiae, Kentucky Whip and Collar Co. v. Illinois Central R. Co., supra note 2.

201 Kentucky Whip and Collar Co. v. Illinois Central R. Co. (1937) 299 U. S. $334,345,346,347,348,351,352$.

202 United States v. Hill, supra note 159, at 425 .

203299 U. S. at 352 .
} 
broad enough to reach cases where "the goods shipped are of themselves harmless," it is difficult to find anything left of the Child Labor opinion, even though that opinion, instead of being overruled, was brushed aside as not in point. ${ }^{204}$

There is a second branch of the Whitfield opinion which merits special consideration. Intimating that possibly the Hawes-Cooper Act was superfluous, the opinion stated: ${ }^{205}$

"... the importation is relieved from the operation of any rule which recognizes a right of sale in the unbroken package without state interference-a right the exercise of which never has been regarded as a fundamental part of the interstate transaction, but only as an incident resulting therefrom .... The interstate transaction in its fundamental aspect ends upon delivery to the consignee.

"... Even without such action by Congress the unbroken-package doctrine, as applied to interstate commerce, has come to be regarded, generally at least, as more artificial than sound. Indeed, in its relation to that commerce, it was definitely rejected . . . as affording no immunity from State taxation ....

"Whether that view of the doctrine as applied to state taxation should now be given a more general application, the Hawes-Cooper Act, being determinative of the case now under review, makes it unnecessary for us to decide."

These are sweeping statements. They threaten to annihilate the "silence of Congress" doctrine in so far as it applies to the sale of imported merchandise, and restrict it to transportation. Possibly the Justice who wrote them was of opinion that if interstate commerce in prisonmade goods can be prohibited, only Congress can do so. In such a case, he wonld have felt called upon to establish the premise that what Ohio was doing did not amount to a regulation of interstate commerce. If so, the reasoning would seem to have become superfluous because of the rejection of the doctrine which called it into being. In the Kentucky Whip and Collar Co. case, the Court makes it clear that what Congress or the states can do concerning intoxicating hquors, they can do concerning convict-made goods. The decision nost relied upon is Clark Distilling Co. v. Western Maryland Ry. Co. ${ }^{206}$ which held that the states can prohibit the importation of intoxicants. It would seem to follow that if there was any barrier to state prohibition of the importation of con-

204 Having pointed out that the power to regulate has been held to include the power to prohibit, the opinion continued: "The ruling in Hammer v. Dagenhart, ... upon which petitioner relies, in no way contravenes or limits the principle of these decisions. In the Hammer case, the Court concluded that the Act of Congress there under consideration had as its aim the placing of local production under federal control." Ibid. at 350 . If the reader has any doubts as to the direct effect of the Hawes-Cooper and Ashurst-Sumners Acts upon "Iocal production," le should refer to the sources cited supra note 199.

205297 U. S. at $439-40$.

200 Supra note 138. 
vict-made goods prior to 1935 , it arose solely from the "silence" of Congress on this point; and that if there is any barrier today, it arises from the fact that Congress, in occupying this field, has failed specifically to authorize coordinate state legislation. Passage of a Webb-Kenyon Act for such goods ${ }^{207}$ would effectively remove this barrier.

Of course, it is equally possible that these paragraphs were inserted to preserve an avenue of escape from the necessity of sustaiming national legislation. If Congressional "silence" is a barrier to state prohibition, it follows that Congress itself can prohibit as well as permit the states to do so. But if the Hawes-Cooper Act was superfluous, no such presumption need follow. Failure to assert a power which the nation does not possess can scarecly be a barrier to state action. The argument would have run somewhat as follows: The sale is no part of interstate commerce. Hence, in prohibiting the sale, the state is not regulating such commerce. Therefore, the fact that the sale may be forbidden furnishes no basis for the conclusion that the interstate traffic in such goods can be prohibited. But if this was the intention, it has already been abandoned in the Kentucky Whip and Collar Co. decision.

The fact that these paragraphs have proved unnecessary does not of itself guarantee that they will prove unimportant. One may confidently predict, however, that such will be the case. The defect in their reasoning is that it is not reahistic. The doctrine that the right to import carries with it the right to sell is too deeply imbedded to be uprooted easily. ${ }^{208}$ It was not without cause that Marshall wrote, "There is no difference, in effect, between a power to prohibit the sale of an article, and a power to prohibit its introduction into the country; the one would be a necessary consequence of the other." ${ }^{209}$ Results under the Hawes-Cooper Act,

207 I must be permitted to dissent from the Chief Justice's assumption, 299 U. S. at 351, indulged in in order to make the Clark Distilling Co. case appear more directly in point, that section 1 of "the Ashurst-Sumners Act as to interstate transportation of convict-1nade goods has substantially the same provisions as the WebbKenyon Act as to intoxicating liquors ...." The presence of the penalty clause (section 3) makes it very doubtful if an interpretation can be placed upon it similar to that given to the parallel language used in the Webb-Kenyon Act when construed in connection with the title of that act. See supra note 138. The AshurstSumners Act is more properly described as modelled on the Reed Amendment, stspra note 159, and United States v. Hill and Williams v. United States, likewise supra note 159, rather than the Clark Distilling Co. case, are the proper precedents. If this confusion contimues, the states may find it relatively easy to establislr a right to coordinate legislation under existing statutes.

208 Indeed, it is doubtful if either this riglit, or the scope of national power to regulate it, stops with the breaking up of the "original package." Thus, the Food and Drugs Act overrides state laws regulating labels on "the immediate container of the article which is intended for consumption by the public" although it has been taken from its "original package" and is on the shelves of the retail merchant. McDermott v. Wisconsin (1913) 228 U. S. 115.

209 Brown v. Maryland, supra note 19, at 438. 
as implemented by the laws of thirty-eight states, ${ }^{210}$ have proved his point. Such a doctrine, instead of protecting interstate commerce from state regulation, would endanger national supremacy through vesting a superior power to prohibit it in the importing states.

This is even clearer when we realize the implications of the proposed rule. Labor legislation has generally followed the pattern, "It is illegal to permit any child under the age of fourteen to work ...." It would be a simple matter to amend such statutes to read, or to supplement them with others reading: "It is illegal to sell ... any goods ... in the manufacture, production, or mining of which any child under the age of fourteen years...." There can be little doubt as to the validity of such acts under the Fourteenth Amendment. If they can apply equally to domestic and imported goods, as the Whitfield opimion intimates, each state is in a position to export its own labor law to every other state or foreign country producing for its market. These laws are so diverse and conflicting that chaos will result. Hence, this would seem to be a logical occasion to apply the doctrine that congressional "silence" is a barrier to state action.

Although it thus is doubtful if this doctrine will materialize, even this tentative advancement will strengthen the case for labor legislation. With these passages before it, the Court will find it more difficult to strike down state statutes prohibiting the sale of imported merchandise. Having once sustained such laws, the pure pressure of business necessity will force the Court to recognize that they constitute regulations of interstate commerce and thus fall within the orbit of national power. The mininum standards which Congress will exact of the states as exporters will thus becoine the maximum standards that they can demand as inporters. We will have returned to the Constitution.

This evolution can be predicted with greater confidence because the doctrine will contain the germ of its own destruction. There is not a single precedent holding that the states cannot prohibit, Congress willing, the importation of any article the sale of which they can forbid. Whatever is said regarding sales, every state prohibition of importation, now that the pre-Cooley case dogma of exclusive national power is dead, must be recognized as a regulation of counmerce. If the states can prohibit importation because it leads to evil, Congress can. If Congress

210 Arizona, Arkansas, California, Colorado, Connecticut, Georgia, Idaho, Illinois, Indiana, Kansas, Kentucky, Louisiana, Maine, Maryland, Massachusetts, Michigan, Mississippi, Montana, Nebraska, New Hampshire, New Jersey, New York, North Carolina, Ohio, Oklahoma, Oregon, Pennsylvania, Rhode Island, Tennessee, Texas, Utah, Virginia and Washington forbid the sale of convict-made goods on the open market. Iowa, Minnesota, New Mexico, South Dakota and Wisconsin forbid their sale unless labeled. Some of the statutes exempt domestic goods, and hence arc of doubtful constitutionality. 
can do so to advance the policies adopted by the states, it can do so to accomplish its own program of reform. The precedents are clear. There is no logical escape from them. State power to prohibit interstate commerce, although of tremendous scope, must remain subordinate to the superior power of Congress.

\section{SUMMARY AND CONCLUSION}

Although many early opinions expressed the belief that exclusive power to regulate commerce lias been vested in Congress, this dictum never became law. Even those who advanced it made concessions which recognized the existence of concurrent power, the most common doctrine being that the police power of the states and the commerce power of the nation overlap. The latter doctrine giving rise to difficulties, the Cooley case abandoned it in favor of a frank recognition of concurrent power to regulate those aspects of commerce which lend themselves to "different systems of regulation, drawn from local knowledge and experience." The remaining pliases, requiring "one uniform system," were to be subject to the exclusive jurisdiction of Congress. Other opimions demonstrated that the first category includes many types of prohibitory legislation, this liaving been the most widely asserted form of state activity. Later cases remade the Cooley test into one of legislative intent rather than of division of powers, the barrier to state action being congressional silence rather than a want of authority. As this new doctrine of "the silence of Congress" got off to a poor start, being used to strike down legislation which liad strong popular support, and the validity of whicl liad long been taken for granted, it lias not proved an effective clieck to state legislation prohibiting commerce. The Court is now threatening to abandon it completely as far as the sale of imported articles is concerned. The principal contribution of the cases in which it was elaborated has been to redefine "exclusive power" to signify little more tlian concurrent autlority subject to the principle of the supremacy of national law, and thus to open the door to extending state power to the full extent of that of the nation itself.

Until a half century ago there liad been little doubt as to the power of the states to prohibit the importation of any articles, the use of whicli they reasonably considered to lead to undesirable consequences. This is clearly seen from the constant exercise of this power together with its frequent recognition in dicta, coupled with a complete absence of efforts to secure adverse rulings. A strong effort was made to establish their power as exclusive, it being argued that prolibition is not regulation and hence is an exercise of a reserved power rather than of the commerce power. Ultimately the contrary view prevailed, so that the right to prolibit became subordinate to the superior authority vested in Congress. 
In 1918 the supporters of this rejected view scored a partial victory in the Child Labor Case, holding that interstate commerce cannot be prohibited by Congress when "the goods shipped are of themselves harmless." The opinion had the novel feature of ruling that the statute trespassed upon the reserved rights of the states as exporters rather than as importers, which necessarily implied that no state could forbid the importation or sale of such goods. Seventeen years later, in a unanimous opinion virtually devoid of explanation, the Court abandoned this position and sustained the power of the states to prohibit the sale of "original packages" of concededly harmless goods because of the type of labor employed in their manufacture and the economic harm resulting from their sale in competition with local products. The ruling would seem to be equally applicable to econonnic harm due to substandard labor conditions where free, rather than convict, labor is employed.

This would seem to be the one field in which the Court might reasonably have resurrected the original form of the Cooley rule and found that the importing states have surrendered their jurisdiction to Congress, which now enjoys exclusive power to govern such commerce. Although it has refused to do this, at least so far as prison-made goods are concerned, it is still possible that it will hold Congress' power to be "exclusive" in the sense in which the word was redefined in the hquor opinions, in which case congressional silence will constitute a bar to state action. In breaking this silence, Congress will be able to set maximum standards beyond which the states as importers cannot go. A third alternative, that in returning this power to the states as inporters the Court has no intention of recognizing even a superior power in Congress, although receiving some support in certain statements in the Whitfield opimion, would lead to such chaotic conditions that it does not merit serious consideration, and appears already to have been rejected.

In what I have written regarding the breadth of effect of the convictmade goods decisions, it has been assumed that those decisions will stand and that they will be given the normal scope which the rules of logic would seem to require. One must not be too certain the second will be done even if the first proves true. The justices may prefer a rule which faces both ways. Whitfield v. Ohio did not nention Hammer v. Dagenhart, and the Kentucky Whip and Collar Co. case "distinguished" it. The Court may prefer to keep both rules, just as in the realm of prohibitary "taxation" it has preserved McCray v. United States"11 as an alternative precedent to Bailey v. Drexel Furniture Co.212 It will then

211 (1904) 195 U. S. 27.

212 (1922) 259 U. S. 20. See Cushman, Social and Economic Control Througls Federal Taxation (1934) 18 MLNN. L. Rev. 759; Grant, op. cit. supra note 186, 751 at 756-72. 
be able to sustain statutes striking at whatever forms of economic harm it considers not to merit judicial protection without weakening its power to strike down statutes that do not meet with its approval. Certainly the opinions in the National Labor Relations Act cases $^{213}$ show no intention to abandon the rule that as a general proposition the regulation of production, even for the interstate market, is beyond the reach of congressional power. But will it not be a sad commentary upon present civilization should the privilege of exploiting the labor of children find a shield in the Constitution, while the privilege of exploiting adult convicts, who profit from the exploitation, does not?

$$
\text { J.A.C. Grant. }
$$

Untuerstty of Caltfornia at Los Angeles, Los Angeres, Carmororna. 